This manuscript has been submitted for publication in EARTH AND PLANETARY SCIENCE LETTERS. Please note that this manuscript has not undergone peer review, nor has it been formally accepted for publication. Subsequent versions of this manuscript may have slightly different content. If accepted, the final version of this manuscript will be available via the 'Peer-reviewed Publication DOI' link on the right-hand side of this webpage. Please feel free to contact the corresponding author; we welcome feedback.

\title{
Primordial and recycled sulfur sampled by the Iceland mantle plume
}

Eemu Ranta $^{1 *}$, Jóhann Gunnarsson-Robin ${ }^{1}$, Sæmundur A. Halldórsson ${ }^{1}$, Shuhei Ono², Gareth Izon $^{2}$, Matthew G. Jackson ${ }^{3}$, Callum D.J. Reekie ${ }^{4}$, Frances E. Jenner ${ }^{5}$, Guðmundur H. Guðfinnsson ${ }^{1}$, Ólafur P. Jónsson ${ }^{1}$, Andri Stefánsson ${ }^{1}$

${ }^{I}$ Nordic Volcanological Center, Institute of Earth Sciences, University of Iceland, Iceland ${ }^{2}$ Department of Earth, Atmospheric and Planetary Sciences, Massachusetts Institute of Technology, USA ${ }^{3}$ Department of Earth Science, University of California, Santa Barbara, USA ${ }^{4}$ Department of Earth Sciences, University of Cambridge, UK

${ }^{5}$ School of Environment, Earth and Ecosystem Sciences, The Open University, UK

*Corresponding author: Eemu Ranta, eemu@hi.is 
3 Stable sulfur isotope ratios of mid-ocean ridge and ocean island basalts (MORBs and OIBs) preserve unique information about early Earth processes and the long-term volatile cycles between Earth's mantle and the surface. Icelandic basalts present ideal material to examine the oldest known terrestrial mantle reservoir, accessed through a deep-rooted mantle plume, but their multiple sulfur isotope systematics have not been explored previously. Here, we present new sulfur concentration (30-1570 ppm), speciation $\left(\mathrm{S}^{6+} / \Sigma \mathrm{S}=0.05-0.43\right)$ and isotope data $\left(\delta^{34} \mathrm{~S}_{\mathrm{S}^{2-}}=-2.5\right.$ to $+3.8 \%$ and $\Delta^{33} \mathrm{~S}_{\mathrm{S}^{2-}}=-0.045$ to $+0.016 \%$; vs. Cañon Diablo Troilite) from a large sample suite $(\mathrm{N}=62)$ focused on subglacially erupted basaltic glasses obtained from Iceland's neovolcanic zones. Using these data along with trace element systematics to account for the effects of crustal magmatic processing (degassing and immiscible sulfide melt formation) on $\delta^{34} \mathrm{~S}$, it is shown that primitive ( $\left.\mathrm{MgO}>6 \mathrm{wt} . \%\right)$, undegassed glasses accurately record the $\delta^{34} \mathrm{~S}$ signatures of their mantle sources. Compared to the depleted MORB source mantle (DMM; $\delta^{34} \mathrm{~S}_{\mathrm{S}^{2-}}=-1.3 \pm 0.3 \%$ ), the Iceland mantle is shown to have a greater range of $\delta^{34} \mathrm{~S}_{\mathrm{S}^{2}}$ values between -2.5 and $-0.1 \%$. Similarly, Icelandic basalts are characterized by more variable and negatively shifted $\Delta^{33} \mathrm{~S}$ values $(-0.035$ to $+0.013 \%)$ relative to DMM $(0.004 \pm 006 \%)$. Negative $\delta^{34} \mathrm{~S}$ and $\Delta^{33} \mathrm{~S}$ signatures are most prominent in basalts from the Snæfellsnes Volcanic Zone and the Kverkfjöll volcanic system, which also have the lowest, most MORB-like ${ }^{3} \mathrm{He} /{ }^{4} \mathrm{He}\left(8-9 \mathrm{R} / \mathrm{R}_{\mathrm{A}}\right.$, where $\mathrm{R}_{\mathrm{A}}$ is the ${ }^{3} \mathrm{He} /{ }^{4} \mathrm{He}$ of air) and the highest $\mathrm{Ba} / \mathrm{La}$ (up to 12) in Iceland. We propose that subduction fluid-enriched, mantle wedge type material in the North Atlantic upper mantle constitutes a low- $\delta^{34} S-\Delta^{33} S$ component in the Icelandic mantle. This suggests that volatile heterogeneity in Iceland, and potentially at other OIBs, may originate not only from diverse plume-associated mantle components, but also from a heterogeneous ambient upper mantle. By contrast, a set of samples with high ${ }^{3} \mathrm{He} /{ }^{4} \mathrm{He}$ (up to $25.9 \mathrm{R} / \mathrm{R}_{\mathrm{A}}$ ) and negative $\mu^{182} \mathrm{~W}$ anomalies define a primordial lower mantle reservoir with a near-chondritic $\delta^{34} S_{\Sigma S}$ and $\Delta^{33} S$ signature of $\sim 0 \%$. This sulfur isotopic signature is difficult to reconcile with the non-chondritic sulfur isotopic signature of the DMM and may reflect either separate conditions during core formation, or a previously unidentified flux of sulfur from the core to the high- ${ }^{3} \mathrm{He} /{ }^{4} \mathrm{He}$ reservoir.

Keywords: sulfur isotopes, ocean island basalts, Iceland, deep volatile recycling, primordial mantle, core-mantle interaction 
Mass-independent $\mathrm{S}$ isotope fractionation signatures (S-MIF; $\Delta^{33} \mathrm{~S} \neq 0$ ) measured in sulfides from the South Pacific Pitcairn and Mangaia hotspots provide remarkable evidence for the resurfacing of Archean sedimentary material through ocean island basalts (OIBs) (Cabral et al. 2013; Delavault et al. 2016). By contrast, the depleted upper mantle (DMM) as sampled by mid-ocean ridge basalts (MORBs) features chondritic $\Delta^{33} \mathrm{~S}$ values $(\sim 0 \%)$ coupled with a sub-chondritic $\delta^{34} \mathrm{~S}$ signature $(-1.28 \pm 0.33 \%$; Labidi et al. 2013), which requires that $\sim 97 \%$ of Earth's sulfur partitioned to the core during core-mantle differentiation (Labidi et al. 2013, 2016; Labidi and Cartigny 2016). Determining the multiple sulfur isotopic composition of high- ${ }^{3} \mathrm{He} /{ }^{4} \mathrm{He}$ OIBs, which are thought to tap primordial lower mantle reservoirs (Yuan and Romanowicz 2017; Mundl-Petermeier et al. 2020), could provide additional constraints on the timing and nature of Early Earth processes, but to date, published data are limited to two highly degassed high- ${ }^{3} \mathrm{He} /{ }^{4} \mathrm{He}$ samples from Samoa (Dottin et al. 2020a).

The mantle plume beneath Iceland samples what is thought to be the oldest and most primordial material available on Earth, i.e., a part of the deep mantle that has remained unstirred by mantle processes since at least $4.45 \mathrm{Ga}$. Such ancient origin is supported by ${ }^{129} \mathrm{Xe}$-excesses that could have been generated only in the earliest Hadean (Mukhopadhyay 2012), the highest modern terrestrial mantle ${ }^{3} \mathrm{He} /{ }^{4} \mathrm{He}$ values (Harðardóttir et al. 2018) and negative $\mu^{182} \mathrm{~W}$ anomalies (Mundl-Petermeier et al. 2019). Nevertheless, spatial co-variation between isotopic and trace element source indicators hints toward a heterogeneous Icelandic mantle, comprising one or more recycled components and ambient upwelling DMM in addition to the high- ${ }^{3} \mathrm{He} /{ }^{4} \mathrm{He}$ component (Hanan et al. 2000; Macpherson et al. 2005; Halldórsson et al. 2016a,b; Harðardóttir et al. 2018; Rasmussen et al. 2020). Due the unique dual role of sulfur as a volatile element in near-surface processes, and its strong partitioning to the core during core-mantle differentiation, the $\delta^{34} \mathrm{~S}$ and $\Delta^{33} \mathrm{~S}$ composition of Icelandic basalts could provide unique constraints on both the early planetary history of Earth and the deep recycling of sulfur through the mantle.

Previously published $\delta^{34} \mathrm{~S}$ values for Icelandic basalts range from -2.0 to $0.4 \%$ (Torssander 1989), but are difficult to interpret in terms of source values due to their highly degassed nature. In this study, we combine a newly developed HF extraction protocol (Labidi et al. 2012) with improved mass spectroscopy (Ono et al. 2006) to generate a high precision quadruple sulfur isotope dataset $\left({ }^{32} \mathrm{~S},{ }^{33} \mathrm{~S},{ }^{34} \mathrm{~S}\right.$ and $\left.{ }^{36} \mathrm{~S}\right)$ measured from dissolved sulfide $\left(\mathrm{S}^{2-}\right)$ in a large set of subglacial basaltic glasses. Importantly, our subglacial glass samples are 
largely devoid of secondary $\delta^{34} \mathrm{~S}$ shifts imposed by degassing and assimilation of seawaterderived sulfate. Instead, the data illuminate the effects of immiscible sulfide melt formation during crustal magmatic evolution on both sulfur speciation $\left(\mathrm{S}^{6+} / \Sigma \mathrm{S}\right)$ and $\delta^{34} \mathrm{~S}$ of dissolved sulfide $\left(\delta^{34} S_{S^{2-}}\right)$, and enables us to constrain the $\delta^{34} S$ and $\Delta^{33} S$ signatures of distinct mantle components beneath Iceland.

\section{SAMPLES \& METHODS}

\subsection{Samples}

Our sample set $(n=62)$ focuses on Pleistocene subglacial glasses $(n=59$; Fig. 1$)$ that represent most of the geochemical range of Icelandic magma series, encompassing rhyolites, andesites and basalts (0.1-9.9 wt.\% MgO; Fig. 2). The samples cover the main on-land rift zones of Iceland, comprising the Northern, Western and Eastern Rift Zones (NRZ, WRZ and ERZ, respectively), as well as the propagating rift of South Iceland Volcanic Zone (SIVZ) and the off-rift Snæfellsnes Volcanic Zone (SNVZ) (Fig. 1). The rift zone lavas are tholeiitic, while the SIVZ and SNVZ lavas are transitional to alkaline. To assess the sulfur isotope systematics of a single magmatic lineage, 15 samples were included from the Kverkfjöll volcanic system, located in the south-eastern flank of the NRZ.

Most subglacial glasses $(n=45)$ were quenched under sufficiently high pressure to prevent significant S degassing (Supplementary Information). Moreover, the potential effect of crustal assimilation on $\mathrm{S}$ isotopic compositions of Icelandic basalts is likely to be small because of the higher S content of deep, undegassed melts (400-1600 ppm) relative to hydrothermally altered crust which is expected to be S-depleted due to degassing and leaching of sulfur by hydrothermal fluids (Alt et al. 1995; Gunnarsson-Robin et al. 2017). An additional advantage of the subglacial glasses is that they are unaffected by assimilation of seawater sulfate-derived $\mathrm{S}$, a process which is known to increase both measured $\mathrm{S}$ concentrations and $\delta^{34} \mathrm{~S}$ values in submarine pillow glasses (Labidi et al. 2014). Absence of seawater-influence in Icelandic subglacial basalts is demonstrated by lack of elevated $\mathrm{Cl} / \mathrm{K}$ ratios above $\sim 0.10$ (Halldórsson et al. 2016a). Thus, subglacial glasses closely capture the pre-eruptive melt compositions with respect to $\mathrm{S}$ concentrations and isotope ratios, presenting a significant advantage over the subaerial samples targeted in the only previous sulfur isotope appraisal in Iceland (Fig. 2a; Torssander, 1989) and many previous sulfur isotope studies on 
101 OIBs (e.g., Dottin et al. 2020a). Three subaerial lavas (A-THO, B-ALK, I-ICE) are included to examine the effect of near-surface degassing on $\mathrm{S}$ concentration, $\mathrm{S}^{6+} / \Sigma \mathrm{S}$ and $\delta^{34} \mathrm{~S}$.

\subsection{Major and trace elements and sulfur speciation}

Major element content, S concentrations and S speciation in the glasses were determined by electron probe microanalysis (EPMA) at the Institute of Earth Sciences, University of Iceland. Trace element analysis was performed using inductively coupled plasma mass spectrometry (ICP-MS) at the Scripps Institution of Oceanography, as well as laser ablation ICP-MS (LA-ICP-MS) at the Research School of Earth Sciences, Australian National University and at the Geological Survey of Finland. Additional details on analytical protocols are provided in the Supplementary Information.

\subsection{Sulfur extraction protocol}

Sulfur was extracted from powdered hand-picked glasses or rock fragments and converted to $\mathrm{Ag}_{2} \mathrm{~S}(\mathrm{~s})$ via the coupled $\mathrm{HF}$ dissolution/Cr reduction method using an all-teflon extraction line (Labidi et al. 2012). The dissolved $\mathrm{S}^{2-}$ was released as $\mathrm{H}_{2} \mathrm{~S}(\mathrm{~g})$ and flushed within a nitrogen stream via a water trap before being precipitated as $\mathrm{Ag}_{2} \mathrm{~S}(\mathrm{~s})$ in a $\mathrm{AgNO}_{3}$ trapping solution. The resultant $\mathrm{Ag}_{2} \mathrm{~S}(\mathrm{~s})$ was heated at $80^{\circ} \mathrm{C}$ for 3-6 hours, cleaned in triplicate using deionized water $(18.2 \mathrm{M} \Omega \cdot \mathrm{cm})$ prior to being dried and weighed. Gravimetric extraction yields were calculated relative to the EPMA-derived S concentrations, and were found to vary between 60 and $110 \%$. Rather than incomplete extractions, this relatively large spread in yields probably reflects a combination of variable crystal content and $\mathrm{S}^{6+} / \Sigma \mathrm{S}$ of the extracted material (Supplementary Information). Importantly, no relationship between yields and measured S isotope values was identified (Fig. S1). Repeated extractions of the relatively aphyric glass STAP-1, with a measured $\mathrm{S}^{6+} \Sigma \mathrm{S}$ of $0.22 \pm 0.03$, returned an average yield of $91 \pm 11 \%(1 \sigma, \mathrm{n}=10)$.

\subsection{Sulfur isotope analysis}

Sulfur isotope ratios were determined via dual-inlet isotope ratio mass spectrometry (IRMS)

133 at the Stable Isotope Geobiology Laboratory at the Massachusetts Institute of Technology

134 (MIT) following the methodology described by Ono et al. (2006, 2012). Here, approximately 
$2 \mathrm{mg}$ of $\mathrm{Ag}_{2} \mathrm{~S}$ was converted into $\mathrm{SF}_{6}(\mathrm{~g})$ via overnight reaction with $\mathrm{F}_{2}(\mathrm{~g})$ at $300^{\circ} \mathrm{C}$. The resultant $\mathrm{SF}_{6}(\mathrm{~g})$ was initially purified cryogenically before being isolated by preparative tandem-column (molecular sieve $5 \AA$ and HayesepQ) gas chromatography. The purified analyte was introduced to a Thermo Scientific MAT 253 IRMS instrument where the mass/charge ratios $127,128,129,131$, corresponding to ${ }^{32,33,34,36} \mathrm{SF}_{5}{ }^{+}$ions, were measured. The ${ }^{34} \mathrm{~S} /{ }^{32} \mathrm{~S}$ data are reported in $\delta$-notation relative to the Vienna Cañon Diablo Troilite (VCDT), following:

$$
\delta^{34} \mathrm{~S}_{\text {sample }}=\frac{\left({ }^{34} \mathrm{~S} /{ }^{32} \mathrm{~S}\right)_{\text {sample }}-\left({ }^{34} \mathrm{~S} /{ }^{32} \mathrm{~S}\right)_{\mathrm{VCDT}}}{\left({ }^{34} \mathrm{~S} /{ }^{32} \mathrm{~S}\right)_{\mathrm{VCDT}}}
$$

The VCDT scale is defined by the IAEA-S- 1 standard with a $\delta^{34} \mathrm{SVCDT}_{\text {value of }-0.3 \% \text { o }}$

146 (Coplen and Krouse, 1998). Deviation from a mass-dependent fractionation line is reported in $147 \Delta$ notation as

$$
\Delta^{\mathrm{x}} \mathrm{S}=\ln \left(\delta^{\mathrm{x}} S+1\right)-\theta^{x} \ln \left(\delta^{34} S+1\right)
$$

where $\mathrm{x}=33$ or $36, \theta^{33}=0.515$ and $\theta^{36}=1.90$. Replicate analyses of an in-house $\mathrm{Ag}_{2} \mathrm{~S}$ standard (Ono-Ag2S), the IAEA-S-1 reference material and three subglacial glasses are reported in Tables S1 and S2. Based on 18 analyses of Ono- $\mathrm{Ag}_{2} \mathrm{~S}$ during our sessions, longterm $\delta^{34} \mathrm{~S}, \Delta^{33} \mathrm{~S}$ and $\Delta^{36} \mathrm{~S}$ reproducibilities are estimated at $0.12,0.004$, and $0.086 \%$ (all $1 \sigma$ ), respectively (Fig. S1). Repeat measurements of IAEA-S-1 yield respective $\delta^{34} \mathrm{~S}, \Delta^{33} \mathrm{~S}$ and $\Delta^{36} \mathrm{~S}$ values of $-1.19 \pm 0.17 \%,+0.100 \pm 0.004 \%$ and $-0.669 \pm 0.068 \%$, relative to the MIT reference gas SG1 (Table S-1). Given the lack of reference materials with certified $\Delta^{33} \mathrm{~S}_{\mathrm{CDT}}$ and $\Delta^{36} \mathrm{~S}_{\mathrm{CDT}}$ values, different laboratories have defined the CDT-scale via measurements of IAEA-S-1 and CDT (Table S3, Fig. S2). Because no CDT measurements have been conducted at the MIT lab, we anchor the CDT scale by defining the respective $\Delta^{33} \mathrm{~S}_{\mathrm{CDT}}$ and $\Delta^{36} \mathrm{~S}_{\mathrm{CDT}}$ values of IAEA-S-1 as +0.109 and $-0.730 \%$, which represents the average of previously established IAEA-S-1 values (Supplementary Information). This makes it possible to compare our dataset with previously published multiple sulfur isotope datasets for MORBs and OIBs.

The relatively large uncertainty associated with $\Delta^{36} \mathrm{~S}$ measurements results from the low natural abundance of ${ }^{36} \mathrm{~S}(0.015 \%)$ and potential isobaric interferences on mass 131

166 (Ono et al. 2006). While $\Delta^{36} \mathrm{~S}$ data is reported for completeness, its large uncertainty relative 167 to the subdued variability within our samples limits its utility beyond that of $\Delta^{33} \mathrm{~S}$. 
Sulfur concentration, speciation and isotope data as well as major and trace element abundances are reported in Tables S-4 and S-5.

Sulfur concentrations. The samples (including both subaerial lavas and subglacial glasses) display variable S concentrations from 30 to $1570 \mathrm{ppm}$. Overall, sulfur concentrations increase from $300-800 \mathrm{ppm}$ in the most primitive subglacial glasses $(9-10$ wt. $\% \mathrm{MgO}$ ) to a peak of $1200-1570 \mathrm{ppm}$ at $6 \mathrm{wt} . \% \mathrm{MgO}$, before decreasing to about 1100 ppm at 4 wt.\% MgO (Fig. 2a). Breaks from these trends are seen in a subset of the subglacial glasses, which show marked S depletions at given $\mathrm{MgO}$ content (Fig. 2a). Lowest sulfur contents are seen in the subaerial lavas (30 to $70 \mathrm{ppm}$ ). The main trend closely follows the pre-eruptive sulfur concentrations as recorded by melt inclusion datasets available for Icelandic basalts (Fig. 2a). Of the other examined trace elements, only $\mathrm{Cu}$ shows a similar trend (Fig. 3a). Hereafter, the two distinct melt evolution trends defined by $\mathrm{S}$ and $\mathrm{Cu}$ are referred to as Phase $1(\mathrm{MgO}>6 \mathrm{wt} . \%)$ and Phase $2(\mathrm{MgO}<6$ wt.\%). Sample A36 has anomalously high $\mathrm{S}$ and $\mathrm{Cu}$ concentrations. Similar over-enrichments in $\mathrm{S}$ are recorded by a subset of basaltic melt inclusions (Fig. 2a), which at other localities has been explained by resorption of sulfides (Reekie et al. 2019; Wieser et al. 2020).

Sulfur speciation. The Icelandic glasses we deem to be less affected by degassing (see section 4.1) have $\mathrm{S}^{6+} / \Sigma \mathrm{S}$ between 0.04 and 0.23 with an average of $0.15 \pm 0.05(1 \sigma, \mathrm{n}=45$; Fig. 2b). This average value is similar to those reported from Samoan $(0.17 \pm 0.11$; Labidi et al. 2015) and Hawaiian basalts (0.15 \pm 0.05 for submarine Kilauea eruption; Jugo et al. 2010) but higher than reported for MORBs $(<0.1$; Jugo et al. 2010). This is compatible with the more oxidized nature of OIBs (Jugo et al. 2010). In contrast, the most degassed samples have elevated $\mathrm{S}^{6+} / \Sigma \mathrm{S}$ of up to 0.43 (Fig. S3). If the degassed samples are removed, two trends emerge: $\mathrm{S}^{6+} / \Sigma \mathrm{S}$ in primitive melts decreases during melt evolution in Phase 1 from $\sim 0.17$ to values of $\sim 0.10$ and then increases to $\sim 0.20$ during Phase 2 (Fig. $2 b$ ).

Sulfur isotopes. The overall variation in $\delta^{34} \mathrm{~S}_{\mathrm{S}^{2-}}$ captured within our Icelandic samples is -2.5 to $+3.8 \%$ o (Fig. 4). This range is similar to previously reported $\delta^{34} \mathrm{~S}$ data for

198 Icelandic lavas (Torssander 1989; Fig. 4a) and exceeds the $\delta^{34} \mathrm{~S}_{\mathrm{S}^{2-}}$ range displayed by 199 MORBs ( -1.8 to $+1.0, \mathrm{n}=68$; Labidi and Cartigny 2016 and sources therein). Nevertheless, positive values are clearly linked to degassed samples (Fig. 4a; Section 4.1; Torssander, 
1989), while undegassed basaltic glasses display a more limited range of $\delta^{34} S_{S^{2-}}$ values from -2.5 to $-0.1 \%$. Thus, Icelandic basalts lack the positive $\delta^{34} \mathrm{~S}$ values characteristic of OIBs at Samoa (Labidi et al. 2015) and the Canary Islands (Beaudry et al. 2018). The most negative $\delta^{34} \mathrm{~S}_{\mathrm{S}^{2}}$-values are observed in the most primitive Kverkfjöll basalts NAL-356 (-2.3\%o) and NAL-585 and $(-2.0 \%)$ and in the highly primitive $(\mathrm{MgO}=9.9 \mathrm{wt} . \%)$ and geochemically depleted WRZ sample MID-1 (-2.5\%). The $\delta^{34} \mathrm{~S}_{\mathrm{S}^{2-}}$ values generally increase with decreasing $\mathrm{MgO}$, a trend that is most clear in the ERZ and Kverkfjöll sample suites (Fig 4b). The $\Delta^{33} \mathrm{~S}$ values of the entire dataset vary between -0.045 and $+0.016 \%$, or between -0.035 to $+0.010 \%$ o $( \pm 0.013,1 \sigma)$ if subaerial samples are excluded (Fig. 5). The Icelandic glasses have an average $\Delta^{33} \mathrm{~S}$ value of $-0.002 \pm 0.010 \%$ o $(1 \sigma, \mathrm{n}=59)$ and extend to more negative values compared to Samoan OIBs $(0.008 \pm 0.007 \%$; $1 \sigma, \mathrm{n}=22$; Labidi et al. 2015, Dottin et al. 2020a) and MORBs (0.004 $\pm 0.006 \%$ o $(1 \sigma, \mathrm{n}=68$; Labidi et al. 2012, 2013, 2014 , Labidi and Cartigny 2016; Fig. 5). Although their average $\Delta^{33} \mathrm{~S}$ values overlap within $1 \sigma$, a statistical student's $t$ test indicates that, as a whole, Icelandic basalts reflect a different population from both Samoan OIBs and MORBs ( $\mathrm{p}$ value $<0.001)$.

4 DISCUSSION

\subsection{Magmatic degassing}

Sulfur degassing from low $-\mathrm{H}_{2} \mathrm{O}$ basaltic magmas commences at pressures of $\sim 150 \mathrm{MPa}$ (Wallace and Edmonds 2011) and thus, should not have significantly affected the preeruptive $\mathrm{S}$ inventory of Icelandic basalts, which are typically stored at considerably higher pressures (e.g. Halldórsson et al. 2018). Therefore, any S degassing observed in subglacial glasses is expected to be solely related to eruptive degassing (Figs. 2a and S3; Supplementary Information). Degassing can lead to either positive or negative $\delta^{34} \mathrm{~S}$ fractionation, expressed as $\varepsilon^{34} S_{\text {gas-melt }}$ (see Eq. 13 for definition; note that $\varepsilon$ is used here for the fractionation factor to avoid confusion with $\Delta$, which is used for denoting S-MIF). The sign of $\varepsilon^{34} S_{\text {gas-melt }}$ is determined by the $\mathrm{S}$ speciation of the gas and the melt, i.e., $\mathrm{SO}_{2} / \mathrm{H}_{2} \mathrm{~S}(\mathrm{~g})$ and $\mathrm{S}^{6+} / \mathrm{S}^{2-}(\mathrm{m})$, respectively (Fig. S4; Supplementary Information). For example, the sign of $\varepsilon^{34} S_{\text {gas-melt }}$ is positive during degassing of oxidized gases from reduced melts (high $\mathrm{SO}_{2} / \mathrm{H}_{2} \mathrm{~S}(\mathrm{~g})$ and low $\mathrm{S}^{6+} / \mathrm{S}^{2}(\mathrm{~m})$ ), and negative during the converse (low $\mathrm{SO}_{2} / \mathrm{H}_{2} \mathrm{~S}(\mathrm{~g})$ and high $\mathrm{S}^{6+} / \mathrm{S}^{2}(\mathrm{~m})$; Fig. S4). 
$0.14 \pm 0.09$ ), deep degassing (with low $\mathrm{SO}_{2} /\left(\mathrm{SO}_{2}+\mathrm{H}_{2} \mathrm{~S}\right)<0.4$ ) at $\mathrm{T}=1200{ }^{\circ} \mathrm{C}$ only leads to modest $\delta^{34} \mathrm{~S}$ fractionation of $\varepsilon^{34} \mathrm{~S}_{\text {gas-melt }}=0 \pm 0.5 \%$ o (Fig. S4a). Predominance of $\mathrm{H}_{2} \mathrm{~S}$ in the gas phase is also shown by clearly increased $\mathrm{S}^{6+} / \Sigma \mathrm{S}$ in the most degassed melts (Fig. S3). Notably, even $30 \%$ degassing is only expected to lead to minor $\delta^{34} S_{\text {melt }}$ fractionation of \pm 0.4 \%o (Fig. 4a). Therefore, identifying and filtering out samples that have only experienced minor amounts of degassing is not necessary, as they closely record their source $\delta^{34} S$ values. more oxidized melts, shifting $\delta^{34} S_{\text {melt }}$ toward more positive values. Such clear degassinginduced changes in $\delta^{34} \mathrm{~S}$ toward more positive values is seen in our most oxidized basaltic sample BOTN-1 $\left(\mathrm{S}^{6+} / \Sigma \mathrm{S}=0.43\right)$ and in the rhyolitic glass A-THO $\left(\mathrm{S}^{6+} / \Sigma \mathrm{S}=0.43\right)$, which are both highly degassed (Fig. 4a). Similarly, the most degassed Icelandic subaerial samples from Torssander (1989) trend toward positive $\delta^{34} \mathrm{~S}$ values (Fig. 4a). This indicates that in general, $\mathrm{S}$ degassing has an oxidizing effect on Icelandic magmas. As the source $\delta^{34} \mathrm{~S}$ values are not accurately preserved in heavily degassed samples (A1, A3, A6, A32, THOR-1, STORID-1, SELJA-1, SAL-601, BOTN-1, HNAUS-1, OLAF-1, NAL-460, KVK-202, KVK205), they are filtered out from Figs. 6a, 7a and 8a and are not considered in subsequent discussion on $\delta^{34} \mathrm{~S}$ signatures.

\subsection{Sulfide immiscibility}

\subsubsection{Quantifying sulfide melt formation}

Immiscible sulfide melts effectively sequester $\mathrm{S}$ and chalcophile elements, such as $\mathrm{Cu}$, from magmas that are sulfide saturated (Bézos et al. 2005; Jenner et al., 2010, Reekie et al. 2019). The observed trend of decreasing $\mathrm{Cu}$ concentrations with decreasing $\mathrm{MgO}$ below c. 6 wt.\% (Fig. 3a) clearly implicates sequestration of $\mathrm{Cu}$ by an immiscible sulfide melt, as has been previously noted in Icelandic whole-rock data (Momme et al. 2003). An analogous trend is observed for $\mathrm{S}$ and $\mathrm{S} / \mathrm{Dy}$, but is less distinct due to degassing-induced scatter (Figs. 2a and $3 c)$.

The kinks observed at $\mathrm{MgO}=6 \mathrm{wt} \%$ for $\mathrm{Cu}, \mathrm{S}, \mathrm{Cu} / \mathrm{Y}$ and $\mathrm{S}^{6+} / \Sigma \mathrm{S}$ define the boundary between Phase 1 (between $\mathrm{MgO}=6-10$ wt.\%) and Phase $2(\mathrm{MgO}=4-6$ wt.\%; Figs. 2 and 3). Similar phases have been identified for Samoan basalts (Labidi et al., 2015). The weight fraction of fractionated sulfide $\left(\mathrm{X}_{\text {sulf }}\right)$ during both phases can be quantified using 


$$
X_{\text {sulf }}=\frac{D_{\mathrm{Cu}}^{\min -l i q}-D_{\mathrm{Cu}}^{\text {sil-liq }}}{D_{\mathrm{Cu}}^{\text {sulf-liq }}-\mathrm{D}_{\mathrm{Cu}}^{\text {sil-liq }}}
$$

where $\mathrm{D}_{\mathrm{Cu}}^{\mathrm{min}-\mathrm{liq}}$, the empirical bulk partition coefficient of $\mathrm{Cu}$ between crystallizing minerals and silicate melt, is estimated using the observed $\mathrm{Cu}$ trends (see Labidi et al. 2014; Supplementary Information). The partition coefficients of $\mathrm{Cu}$ between silicate minerals and silicate melt, $\mathrm{D}_{\mathrm{Cu}}^{\mathrm{min}-\text { liq }}$, and between sulfide and silicate melts, $\mathrm{D}_{\mathrm{Cu}}^{\text {sulf-liq }}$ are taken as 0.1 and 900, respectively (Lee et al. 2012; Labidi et al. 2014). This yields $X_{\text {sulf }}=800$ ppm for Phase 1 and $2580 \mathrm{ppm}$ for Phase 2 for Icelandic melts. Physical evidence of sulfide saturation during Phase 2 is preserved as $\mathrm{Cu}$-rich sulfide globule inclusions observed in melt inclusions (Fig. S7). However, the apparent early fractionation of sulfides during Phase 1 may be an artefact of the sulfide fractionation model, as the relatively low S contents in Phase 1 melts fall below [SCSS ${ }^{2-}$ ( $\mathrm{S}$ concentrations at sulfide saturation; Fig. 2a; Fortin et al., 2015). Alternatively, the lower-than-expected $\mathrm{Cu}$ increase and the negatively sloping $\mathrm{Cu} / \mathrm{Y}$ trend during Phase 1 could be a result of melt-mixing processes (Shorttle and Maclennan 2011).

We interpret these results to show that Icelandic melts become sulfide saturated below $\mathrm{MgO}=6$ wt.\% (cf. Halldórsson et al. 2018). In this respect, Icelandic melts contrast with MORBs, that fractionate sulfides throughout their crustal evolution path (Bézos et al. 2005). Instead, this behavior is more similar to arc magmas, where the onset of magnetite crystallization leads a reduction in melt $\mathrm{f}_{\mathrm{O} 2}$, triggering sulfide saturation at about 2-3 wt.\% $\mathrm{MgO}$ (Jenner et al. 2010), a process also suggested to explain the $\mathrm{Cu}$ versus $\mathrm{MgO}$ trend observed at Samoa (Labidi et al. 2015). However, in Icelandic magma series the onset of Phase 2 clearly predates the onset of magnetite formation, which is observed only in glasses with $\mathrm{MgO}<5$ wt.\%. A more complex pattern of multiple starts and stops in sulfide saturation during magmatic evolution that are reported for basalts from the Kilauea volcano in Hawaii (Wieser et al., 2020) are not strictly required to explain the Iceland data, although we cannot rule out the possibility that some melts were sulfide saturated at higher pressures and became undersaturated upon ascent to higher level crustal magma chambers (Reekie et al., 2019; Wieser et al., 2020). 
In a non-redox buffered system, sulfide fractionation leads to an increase in the melt $\mathrm{S}^{6+} / \Sigma \mathrm{S}$

300 and thereby an increase in melt $\delta^{34} S_{\Sigma S}$ values because $S^{6+}$ is isotopically heavier than $S^{2-}$

$301\left(\varepsilon^{34} \mathrm{~S}_{\text {sulfate-sulfide }} \approx+3 \%\right.$ at $\left.\mathrm{T}=1250^{\circ} \mathrm{C}\right)$. In this case, no change in melt $\delta^{34} \mathrm{~S}_{\mathrm{S}^{2-}}$ values should

302 be observed (Fig. S6; Labidi et al. 2015). However, if $\mathrm{S}^{6+} / \Sigma \mathrm{S}$ is buffered during sulfide

303 fractionation by another multivalent element, conversion of $\mathrm{S}^{6+}$ to $\mathrm{S}^{2-}$ leads to a gradual

304 increase in both melt $\delta^{34} \mathrm{~S}_{\Sigma \mathrm{S}}$ and $\delta^{34} \mathrm{~S}_{\mathrm{S}^{2-}}$ (Fig. $4 \mathrm{~b}$; Supplementary Information). This

305 buffering effect means that the $\delta^{34} \mathrm{~S}$ values of moderately oxidized basalts that have

306 fractionated sulfides, like those in Iceland, may be more positive than their mantle sources

307 (Labidi et al. 2015).

308 The observed increase in $\mathrm{S}^{6+} / \Sigma \mathrm{S}$ below $6 \mathrm{wt} . \% \mathrm{MgO}$ falls short of the modeled

309 increase expected from sequestration of $\mathrm{S}^{2-}$ by sulfides (Fig. 2b), suggesting that at least some

310 buffering of $\mathrm{S}^{6+} / \Sigma \mathrm{S}$ takes place in the melts. Iron may act as a redox buffer through the

311 electron-exchange reaction (Fig. S5; Jugo et al. 2010).

$$
\mathrm{S}^{6+}+8 \mathrm{Fe}^{2+} \rightleftharpoons \mathrm{S}^{2-}+8 \mathrm{Fe}^{3+}
$$

315 In the Kverkfjöll samples, a subtle trend of increasing $\delta^{34} \mathrm{~S}_{\mathrm{S}^{2-}}$ from $-2.2 \%$ to $-0.9 \%$ is

316 observed during melt evolution between 7.5 to $4.0 \mathrm{wt} . \% \mathrm{MgO}$ (Fig. 4b). A parallel

$317 \delta^{34} \mathrm{~S}_{\mathrm{S}^{2}}$-versus $\mathrm{MgO}$ trend defined by the WRZ-ERZ-NRZ samples is offset to more positive

$318 \delta^{34} \mathrm{~S}_{\mathrm{S}^{2-}}$ values by $\sim 0.5 \%$. The observed trends could be explained by redox buffering-

319 induced $\delta^{34} \mathrm{~S}$ fractionation during sulfide melt formation. However, the large $\delta^{34} \mathrm{~S}$ variability

320 in more primitive samples $(\mathrm{MgO}>6 \mathrm{wt} . \%)$ cannot be explained by melt derivation from a

321 homogenous mantle source, even if sulfide formation during Phase 1 is allowed (Fig. 4b).

322 Instead, the data is most easily explained by primary melt variability of $\delta^{34} \mathrm{~S}_{\mathrm{S}^{2-}}$ between

323 approximately -2.5 and $-0.1 \%$.

\subsection{Sulfur heterogeneity in the Iceland mantle}

327 Given that partial melting does not fractionate $\mathrm{S}$ isotopes, the $\delta^{34} \mathrm{~S}, \Delta^{33} \mathrm{~S}$ and $\Delta^{36} \mathrm{~S}$ values of mantle protoliths are passed on to primary mantle melts (Labidi and Cartigny 2016). While subsequent melt mixing in lower crustal or sub-Moho magma reservoirs may blunt the most extreme source signatures, bulk measurements of relatively primitive glasses are able to capture a major part of the existing mantle heterogeneity in Iceland (Shorttle and Maclennan 
2011). Other types of crustal magmatic processing, such as sulfide immiscibility and crustal assimilation, are only expected to have a minor effect on the $\delta^{34} \mathrm{~S}$ signatures of primitive $(\mathrm{MgO}>6 \mathrm{wt} . \%)$, undegassed samples (Sections 4.1 and 4.2$)$. We consider the $\delta^{34} \mathrm{~S}_{\mathrm{S}^{2-}}$ values of such samples to be representative of primary melt compositions within instrumental error. Degassed samples, and samples with $\mathrm{MgO}$ lower than $6 \mathrm{wt} . \%$ are filtered out in Figs. 6a, 7a and $8 \mathrm{a}$. The $\Delta^{33} \mathrm{~S}$ values are not affected by either degassing, sulfide melt fractionation (Labidi et al. 2014) or $\mathrm{S}^{6+} / \Sigma \mathrm{S}$, so all $\Delta^{33} \mathrm{~S}$ glass analyses are thought to reflect source values and are plotted in Figs. 6-9. In Figs. 6a, 7a and $8 \mathrm{a}$ we plot the $\delta^{34} \mathrm{~S}_{\Sigma \mathrm{S}}$ value that is calculated

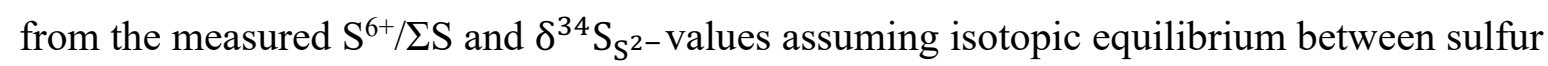
species so that

$$
\delta^{34} \mathrm{~S}_{\Sigma \mathrm{S}}=\mathrm{S}^{6+} / \Sigma \mathrm{S} \times\left(\Delta^{34} \mathrm{~S}_{\text {sulfate-sulfide }}+\delta^{34} \mathrm{~S}_{\mathrm{S}^{2-}}\right)+\left(1-\mathrm{S}^{6+} / \Sigma \mathrm{S}\right) \times \delta^{34} \mathrm{~S}_{\mathrm{S}^{2-}}
$$

This adjustment is made in order to be able to compare our $\delta^{34} \mathrm{~S}$ data with published MORB data. MORBs are almost devoid of sulfate $\left(\mathrm{S}^{6+} / \Sigma \mathrm{S} \approx 0\right.$; Labidi et al. 2014) so that $\delta^{34} \mathrm{~S}_{\Sigma \mathrm{S}} \approx$ $\delta^{34} \mathrm{~S}_{\mathrm{S}^{2-}}$, whereas the Icelandic samples are more oxidized and their measured $\delta^{34} \mathrm{~S}_{\mathrm{S}^{2-}}$ underestimate $\delta^{34} \mathrm{~S}_{\Sigma \mathrm{S}}$ values by approximately $0.1-0.7 \%$.

\subsubsection{Mantle sulfur isotopic signatures and relationship to other mantle source indicators}

The large $\delta^{34} \mathrm{~S}$ variability identified in the Iceland mantle $\left(\delta^{34} \mathrm{~S}_{\mathrm{S}^{2-}}=-2.5\right.$ to $-0.1 \%$, or equivalently, $\delta^{34} \mathrm{~S}_{\Sigma \mathrm{S}}=-1.8$ to $+0.5 \%$ ) exceeds that of unaltered MORBs and points to mantle heterogeneity with respect to sulfur (Figs. 4, 6-8). If sulfur shares a common history with known Icelandic mantle components, a correlation is expected between $\delta^{34} \mathrm{~S}-\Delta^{33} \mathrm{~S}$ and traditional tracers of mantle heterogeneity, such as $\mathrm{Nb} / \mathrm{Zr},{ }^{3} \mathrm{He} /{ }^{4} \mathrm{He}$ and ${ }^{206} \mathrm{~Pb} /{ }^{204} \mathrm{~Pb}$.

The three most depleted samples $(\mathrm{Nb} / \mathrm{Zr}<0.05)$ show the greatest variation in $\delta^{34} \mathrm{~S}_{\Sigma \mathrm{S}}$ values, representing the full of range of Icelandic mantle values of -1.8 to $+0.5 \%$ o (Fig. 6a). Similar, but slightly smaller $\delta^{34} \mathrm{~S}_{\Sigma \mathrm{S}}$ variation of -1.8 to $0.0 \%$ is found in the most enriched samples $(\mathrm{Nb} / \mathrm{Zr}>0.10)$. Whereas enriched trace element signatures in Iceland are tied to enriched radiogenic isotope signatures (Shorttle and Maclennan 2011), the apparent lack of correlation of $\mathrm{Nb} / \mathrm{Zr}$ with $\delta^{34} \mathrm{~S}$ or $\Delta^{33} \mathrm{~S}$ (Fig. 6) indicates that sulfur is partly decoupled from the lithophile, non-volatile elements and their isotopes. However, $\delta^{34} \mathrm{~S}-\Delta^{33} \mathrm{~S}$ signatures can be tied to Icelandic mantle components using available ${ }^{206} \mathrm{~Pb} /{ }^{204} \mathrm{~Pb}$ (Fig. 7) and ${ }^{3} \mathrm{He} /{ }^{4} \mathrm{He}$ (Fig. 8) 
data, which have been used to demarcate primordial, recycled, and local DMM components in the Iceland plume (e.g., Hanan et al. 2000, Füri et al. 2010). Four mantle components are required to explain the combined ${ }^{3} \mathrm{He} /{ }^{4} \mathrm{He}-\delta^{34} \mathrm{~S}-\Delta^{33} \mathrm{~S}-{ }^{206} \mathrm{~Pb} /{ }^{204} \mathrm{~Pb}$ systematics:

(1) Local DMM contributes a low- ${ }^{3} \mathrm{He} /{ }^{4} \mathrm{He}\left(8 \pm 1 \mathrm{R}_{\mathrm{A}}\right)$ Icelandic end-member with typical MORB-like $\delta^{34} \mathrm{~S}_{\Sigma \mathrm{S}}=-1.3 \%$ and $\Delta^{33} \mathrm{~S}=0 \%$. The samples closest to the DMM component come from the NRZ (cf. Hanan et al. 2000).

(2) Plume 1 component has non-radiogenic ${ }^{206} \mathrm{~Pb} /{ }^{204} \mathrm{~Pb}(18.2-18.5)$ and is tied to one of the highest modern ${ }^{3} \mathrm{He} /{ }^{4} \mathrm{He}$ of $33.6 \mathrm{R}_{\mathrm{A}}$ measured in present-day hotspots (Jackson et al. $2020)$, representing a primordial mantle component. This component has DMM-like $\Delta^{33} \mathrm{~S}$ of $0 \%$ but a higher $\delta^{34} \mathrm{~S}_{\Sigma \mathrm{S}}$ value of $\sim 0 \%$. Plume 1 is expressed most clearly by the ERZ basalts in central Iceland, close to the suggested center of the plume (Rasmussen et al. 2020).

(3) Plume 2 is a second Icelandic high- ${ }^{3} \mathrm{He} /{ }^{4} \mathrm{He}$ component (up to $25.7 \mathrm{R}_{\mathrm{A}}$ ) marked by radiogenic ${ }^{206} \mathrm{~Pb} /{ }^{204} \mathrm{~Pb}(19.1-19.3)$ (Mundl-Petermeier et al. 2019, Jackson et al. 2020). It is exclusively sampled by the propagating rift volcanoes in the SIVZ, which have an average $\Delta^{33} \mathrm{~S}$ value of $0.004 \pm 0.005 \%$. The $\delta^{34} \mathrm{~S}_{\Sigma \mathrm{S}}$ of Plume 2 is assumed to be $-1.2 \%$ based on the most primitive SIVZ sample THRI-2. Plume 2 component is thought to represent intermingling of primordial mantle with recycled oceanic crust (Rasmussen et al. 2020). This proposed origin of Plume 2 component is consistent with its DMM-like $\delta^{34} S_{\Sigma S}-\Delta^{33} S$ signature, as the $\delta^{34} \mathrm{~S}$ of oceanic lithosphere is approximately preserved during subduction to the deep mantle (Alt 1995; Li et al. 2020).

(4) To explain the low- $\delta^{34}$ S trend defined by Kverkfjöll lavas (Section 4.2; Fig. 4b) and the tendency of Iceland lavas toward negative $\Delta^{33} \mathrm{~S}$ signatures compared to DMM (Fig. 5), we propose a previously unrecognized Icelandic mantle component - Enriched Mantle Wedge (EMW). Based on the ${ }^{3} \mathrm{He} /{ }^{4} \mathrm{He}-\delta^{34} \mathrm{~S}-\Delta^{33} \mathrm{~S}$ systematics (Fig. 8), EMW is assigned negative $\delta^{34} \mathrm{~S}_{\Sigma \mathrm{S}}$ and $\Delta^{33} \mathrm{~S}$ values of $-2.5 \%$ and $-0.040 \%$, respectively, and a DMM-like ${ }^{3} \mathrm{He} /{ }^{4} \mathrm{He}$ of $8 \mathrm{R}_{\mathrm{A}}$. EMW is sampled most clearly by Kverkfjöll lavas, but its influence is seen across lavas from all rift zones as negatively trending $\delta^{34} \mathrm{~S}_{\Sigma \mathrm{S}}$ and $\Delta^{33} \mathrm{~S}$ values with decreasing ${ }^{3} \mathrm{He} /{ }^{4} \mathrm{He}$ (Fig. 8). The three lowest- $\delta^{34} \mathrm{~S}$ samples (MID-1, NAL-356, NAL-585) all have similar ${ }^{206} \mathrm{~Pb} /{ }^{204} \mathrm{~Pb}$ of $\sim 18.5$, which is taken as the signature of EMW. The SNVZ basalts also have MORB-like ${ }^{3} \mathrm{He} /{ }^{4} \mathrm{He}$ and the lowest $\Delta^{33} \mathrm{~S}$ (down to $-0.035 \%$ ) in Iceland, suggesting contributions from the EMW component (Fig. 8b). However, as the SNVZ samples are evolved and highly degassed, their source $\delta^{34} \mathrm{~S}$ signature cannot be inferred. 
400 Previous observations of non-zero $\Delta^{33} \mathrm{~S}$ values in OIBs from Mangaia (Cabral et al. 2014;

401 Dottin et al. 2020b) and Pitcairn (Delavault et al. 2016) provide evidence for the resurgence

402 of deep recycled Archaean sediments - the only known major terrestrial reservoir with S-MIF

403 signatures $\left(\Delta^{33} \mathrm{~S}\right.$ between -2.5 and $11.5 \%$; Johnston 2011). The large negative $\Delta^{33} \mathrm{~S}$

404 anomalies at Pitcairn and Mangaia are coupled to highly negative $\delta^{34} \mathrm{~S}$ (Cabral et al. 2014,

405 Delavault et al. 2016). Subducted sediments are also thought to form a positive $\delta^{34}$ S end-

406 member in the MORB source mantle (Labidi et al. 2013, 2014), the Samoan EM2 component

407 (Labidi et al. 2015), as well as the Canary Islands HIMU component (Beaudry et al. 2018),

408 which all lack resolvable $\Delta^{33} \mathrm{~S}$ anomalies.

$409 \quad$ Negative $\Delta^{33} \mathrm{~S}$ and $\delta^{34} \mathrm{~S}$ values in Icelandic basalts are tied to a mantle component

410 with MORB-like ${ }^{3} \mathrm{He} /{ }^{4} \mathrm{He}$ and ${ }^{206} \mathrm{~Pb} /{ }^{204} \mathrm{~Pb}$ (Figs. 7 and 8), but also elevated Ba/La (Fig. S8).

411 These characteristics are compatible with subduction fluid-enriched mantle wedge (EMW)

412 type component, i.e., a DMM-like component that has been enriched with sediment-derived

413 fluids from a subducting plate (cf. Richter et al. 2020). Influx of subduction-related volatiles

414 to the upper mantle from subducting slabs is thought to contribute to the volatile

415 heterogeneity of MORB sources (Dixon et al. 2017), including the North Atlantic mantle, as

416 well as Iceland (Halldórsson et al. 2016b; Hauri et al. 2018, Richter et al. 2020). As ambient

417 DMM constitutes a geochemical endmember in Icelandic basalts (Hanan et al. 2000), it is

418 worthwhile to entertain the possibility that the EMW component represents a local upper

419 mantle anomaly resulting from shallow subduction-fluid metasomatism, rather than a deep-

420 sourced plume component.

421 Plausible past subduction events in the region that could have produced the EMW

422 component include Palaeozoic subduction episodes that lead to the closure of the proto-

423 Atlantic Iapetus ocean (Halldórsson et al. 2016b; Hauri et al. 2018) and the Early Cretaceous

424 South Anuyi subduction event (145-120 Ma; Richter et al. 2020).

425 Subduction fluids are potent agents of mantle metasomatism, and may transport 6-20

$426 \%$ of the $\mathrm{S}$ budget of the slab to the the mantle wedge region at 30-230 km depth (Jégo and

427 Dasgupta 2013; Li et al. 2020). Fluids equilibrated with subducting metasediments at $\sim 100$

$428 \mathrm{~km}$ depth have highly negative $\delta^{34} \mathrm{~S}$ values of down to $-8 \%$ and high sulfur concentrations of

$429 \sim 1$ wt.\% (Li et al. 2020). Sediment-derived fluids could also acquire measurable negative

$430 \quad \Delta^{33} \mathrm{~S}$ signatures through even minor incorporation of Archaean sediments derived from

431 continental margins adjacent to the subduction zone. Thus, subduction fluid metasomatism

432 could potentially lead to lowered $\delta^{34} \mathrm{~S}$ and $\Delta^{33} \mathrm{~S}$ of the mantle wedge. The EMW component 
can be created by an admixture of DMM, and $\sim 0.5 \mathrm{wt} . \%$ of metasediment-derived subduction

434 fluid with moderately negative $\delta^{34} S$ and $\Delta^{33} \mathrm{~S}$ signatures of $-5 \%$ and $-0.130 \%$, respectively 435 (Fig. 8).

436 Subduction fluids are also enriched in fluid-mobile elements like Ba, leading to 437 elevated $\mathrm{Ba} / \mathrm{La}$ in arc and back-arc basin basalts and mantle wedges (Leeman et al. 1994). A 438 negative correlation is observed between $\mathrm{Ba} / \mathrm{La}$ and ${ }^{3} \mathrm{He} /{ }^{4} \mathrm{He}$ in Icelandic basalts (Fig. S8), 439 supporting the presence of an Icelandic mantle component that resembles subduction fluid440 enriched DMM. For example, the Kverkfjöll and SNVZ samples that have the lowest $441{ }^{3} \mathrm{He} /{ }^{4} \mathrm{He}, \delta^{34} \mathrm{~S}$ and $\Delta^{33} \mathrm{~S}$ values in Iceland, also have highest $\mathrm{Ba} / \mathrm{La}(10.4-12.4)$. A fluid442 enriched source for the SNVZ basalts is also suggested by their elevated W concentrations (Mundl-Petermeier et al. 2019).

As opposed to a deep-sourced plume component, we propose that EMW represents a shallow low- $\delta{ }^{34} \mathrm{~S}-\Delta^{33} \mathrm{~S}$ mantle anomaly in the North Atlantic upper mantle, created during past subduction events in the region, that has become captured en passant by the upwelling Iceland mantle plume.

\subsection{Implications for the origin of sulfur in the primordial mantle}

Assuming that the association of high- ${ }^{3} \mathrm{He} /{ }^{4} \mathrm{He}$ Iceland samples with ${ }^{129} \mathrm{Xe}$ anomalies and negative $\mu^{182} \mathrm{~W}$ (where $\mu^{182} \mathrm{~W}$ represents deviations of the modern upper mantle ${ }^{182} \mathrm{~W} /{ }^{184} \mathrm{~W}$ in ppm) is indicative of an early-Hadean origin (>4.45 Ga; Mukhopadhyay 2012; Mundl-Petermeier et al. 2019), the formation of the high- ${ }^{3} \mathrm{He} /{ }^{4} \mathrm{He}$ mantle domain predates the oldest surviving terrestrial crust (Jack Hill zircons, up to $4.40 \mathrm{Ga}$; Wilde et al. 2001) and the peak of late accretion at 4.2-4.0 Ga (Bottke and Norman 2017). This primordial mantle domain is associated spatially with ultra-low seismic wave velocity zones (ULVZs) identified at the base of the mantle at the roots of the high- ${ }^{3} \mathrm{He} /{ }^{4} \mathrm{He}$ plumes Hawaii, Iceland and Samoa (Yuan and Romanowicz 2017 and references therein). The hot, potentially partly molten state of ULVZs could promote transport of elements, including S, across the core-mantle boundary (Rizo et al. 2019, Mundl-Petermeier et al. 2020). Thus, the sulfur isotopic fingerprint of the high $-{ }^{3} \mathrm{He} /{ }^{4} \mathrm{He}$ mantle has the potential to constrain key questions remaining about Early Earth processes, as well as the nature and extent of core-mantle interaction (e.g., Mundl-Petermeier et al. 2020).

Our access to undegassed subglacial glass samples allows us to make the first estimate of the $\delta^{34} \mathrm{~S}_{\Sigma \mathrm{S}}$ signature of the high- ${ }^{3} \mathrm{He} /{ }^{4} \mathrm{He}$ mantle. Icelandic basalts show increasing 
$467 \quad \delta^{34} \mathrm{~S}_{\Sigma \mathrm{S}}$ values with increasing ${ }^{3} \mathrm{He} /{ }^{4} \mathrm{He}$, projecting toward a primordial plume component with a near-chondritic $\delta^{34} \mathrm{~S}_{\Sigma \mathrm{S}}$ value of $\sim 0 \%$ (Plume 1 in Fig. $8 \mathrm{a}$ ). This chondritic $\delta^{34} \mathrm{~S}_{\Sigma \mathrm{S}}$ signature contrasts with the distinctly negative, non-chondritic $\delta^{34} \mathrm{~S}_{\Sigma \mathrm{S}}$ signature of the DMM ($1.28 \pm 0.33 \%$; Labidi et al. 2013) and poses the question of why they are different.

The negative $\delta^{34} \mathrm{~S}_{\Sigma \mathrm{S}}$ signature of DMM has been explained to result from core-mantle segregation, because the metallic iron alloy that forms the core is enriched in ${ }^{34} \mathrm{~S}$ during metal-silicate equilibration (i.e., $\varepsilon^{34} S_{\text {metal-silicate }}>0$; Labidi et al., 2013, 2016, Labidi and Cartigny 2016). Depletions of highly siderophile elements (HSEs) in high- ${ }^{3} \mathrm{He} /{ }^{4} \mathrm{He}$ lavas relative to chondrites indicate that the high- ${ }^{3} \mathrm{He} /{ }^{4} \mathrm{He}$ mantle domain experienced core extraction (Mundl et al. 2017, 2020), similarly to MORBs. If we accept the Labidi and Cartigny (2016) model, the high ${ }^{3} \mathrm{He} /{ }^{4} \mathrm{He}$ mantle would be expected to have a non-chondritic and negative $\delta^{34} \mathrm{~S}_{\Sigma \mathrm{S}}$ signature. Thus, the contrasting $\delta^{34} \mathrm{~S}_{\Sigma \mathrm{S}}$ signatures of DMM and the high${ }^{3} \mathrm{He} /{ }^{4} \mathrm{He}$ mantle present an apparent paradox. Below, we discuss mechanisms that could affect the $\mathrm{S}$ isotopic composition of the two mantle reservoirs differently.

First, it is conceivable that sulfur was extracted from the high $-{ }^{3} \mathrm{He} /{ }^{4} \mathrm{He}$ mantle during core formation at conditions where ${ }^{34} \mathrm{~S} /{ }^{32} \mathrm{~S}$ fractionation is negligible. If the high- ${ }^{3} \mathrm{He} /{ }^{4} \mathrm{He}$ mantle equilibrated with a metallic iron alloy at higher temperature compared to the DMM, the accompanying $\varepsilon^{34} \mathrm{~S}_{\text {metal-silicate }}$ fractionation factor could be considerably smaller. However, extrapolation of $\varepsilon^{34} \mathrm{~S}_{\text {metal-silicate }}$ from experimental conditions (up to $1.5 \mathrm{GPa}$ and $1650{ }^{\circ} \mathrm{C}$; Labidi et al. 2016) to lower mantle conditions (up to $136 \mathrm{GPa}$ and $4000 \mathrm{~K}$ at the coremantle boundary at present) is difficult because of the opposing effects of increasing $\mathrm{T}$ (decreases ${ }^{34} \mathrm{~S} /{ }^{32} \mathrm{~S}$ fractionation) and $\mathrm{P}$ (increases ${ }^{34} \mathrm{~S} /{ }^{32} \mathrm{~S}$ fractionation; Labidi and Cartigny 2016). Alternatively, rather than resulting from metal/silicate equilibrium, it is possible that the $\mathrm{S}$ isotopic signature of the high $-{ }^{3} \mathrm{He} /{ }^{4} \mathrm{He}$ mantle is controlled by equilibrium with a sulfide liquid phase ("Hadean matte"; O’Neill 1991) which is associated with negligible ${ }^{34} \mathrm{~S} /{ }^{32} \mathrm{~S}$ fractionation (Labidi and Cartigny 2016). Although the fraction of $\mathrm{S}$ in the mantle affected by sulfide-silicate equilibrium is estimated to be less than $\sim 10 \%$ (Labidi and

494 Cartigny 2016), the high- ${ }^{3} \mathrm{He} /{ }^{4} \mathrm{He}$ mantle could be disproportionally affected compared to the DMM due to its location at the base of the mantle, where a 2-35 km layer of sulfide liquid is thought to have ponded at the late stage of core-mantle differentiation (Savage et al. 2015). Either of these scenarios could potentially explain the contrasting $\delta^{34} S_{\Sigma S}$ signatures of the high- ${ }^{3} \mathrm{He} /{ }^{4} \mathrm{He}$ mantle and the DMM by only invoking core extraction from the silicate mantle. Second, the S isotopic composition of the high- ${ }^{3} \mathrm{He} /{ }^{4} \mathrm{He}$ mantle could be influenced by core-mantle exchange through similar mechanisms that have been recently suggested to 
explain negative $\mu^{182} \mathrm{~W}$ anomalies present in high- ${ }^{3} \mathrm{He} /{ }^{4} \mathrm{He}$ lavas (Mundl et al. 2017, MundlPetermeier et al. 2020, Jackson et al. 2020). Combined ${ }^{3} \mathrm{He} /{ }^{4} \mathrm{He}-\Delta^{33} \mathrm{~S}-\mu{ }^{182} \mathrm{~W}$ data from Iceland and Samoa - the only high- ${ }^{3} \mathrm{He} /{ }^{4} \mathrm{He}$ locations where coupled data are available show that Samoan and Icelandic basalts converge toward near- $0 \Delta^{33} \mathrm{~S}$ values with increasing ${ }^{3} \mathrm{He} /{ }^{4} \mathrm{He}$ (Fig. 8b) and decreasing $\mu^{182} \mathrm{~W}$ (Fig. 9). The chondritic $\Delta^{33} \mathrm{~S}$ signature of high${ }^{3} \mathrm{He} /{ }^{4} \mathrm{He}$ lavas corroborates the suggestion that they sample a primordial mantle least modified by subducted crustal materials (Jackson et al. 2020). The coupled ${ }^{3} \mathrm{He} /{ }^{4} \mathrm{He}-\delta^{34} \mathrm{~S}$ (Fig. 8a) and ${ }^{3} \mathrm{He} /{ }^{4} \mathrm{He}-\Delta^{33} \mathrm{~S}-\mu{ }^{182} \mathrm{~W}$ (Figs. 8b and 9) systematics suggest that the nearchondritic $\delta^{34} \mathrm{~S}_{\Sigma \mathrm{S}}$ is linked to negative $\mu^{182} \mathrm{~W}$. Therefore, it is important to explore whether a single process could explain the $\delta^{34} \mathrm{~S}_{\Sigma \mathrm{S}}-\Delta^{33} \mathrm{~S}-\mu{ }^{182} \mathrm{~W}$ signature of the high- ${ }^{3} \mathrm{He} /{ }^{4} \mathrm{He}$ mantle.

The main current hypothesis to explain the negative correlation between $\mu^{182} \mathrm{~W}$ and ${ }^{3} \mathrm{He} /{ }^{4} \mathrm{He}$ in OIBs is to incorporate $\mathrm{W}$ from the core, which is inferred to have very low $\mu^{182} \mathrm{~W}$ (-220 ppm) and high W concentration ( $\sim 500$ ppb) (Mundl-Petermeier et al., 2019, 2020; Rizo et al. 2019). The core is also the main reservoir of Earth's sulfur, with a 100-fold higher $\mathrm{S}$ content relative to the mantle (approximately $2 \mathrm{wt} . \%$ and $200 \mathrm{ppm}$, respectively) and an assumed chondritic $\Delta^{33} \mathrm{~S}-\delta^{34} \mathrm{~S}$ signature (Labidi et al. 2013). Thus, incorporation of small amounts of core material could simultaneously explain both the negative $\mu^{182} \mathrm{~W}$ and the chondritic $\delta^{34} \mathrm{~S}$ signature of the high ${ }^{3} \mathrm{He} /{ }^{4} \mathrm{He}$ mantle. However, because OIBs are not enriched in highly siderophile elements (HSEs), input of bulk core metal in plume sources is considered unlikely (Mundl-Petermeier 2020). Instead, Mundl-Petermeier et al. (2020) hypothesized that equilibration of the metallic outer core and a basal layer of a primordial magma ocean could produce a remnant lower mantle reservoir with core-like $\mu^{182} \mathrm{~W}$ signature without elevated HSE abundances. However, if the the $\varepsilon^{34} S_{\text {metal-silicate fractionation factor }}$ remains positive at lower mantle P-T-conditions (Labidi et al. 2016), applied to S, the coremantle equilibration model of Mund-Petermeier et al. (2020) would generate (or maintain) a negative $\delta^{34} \mathrm{~S}_{\Sigma \mathrm{S}}$ signature for the high- ${ }^{3} \mathrm{He} /{ }^{4} \mathrm{He}$ mantle, failing to explain its chondritic $\delta^{34} \mathrm{~S}_{\Sigma \mathrm{S}}$ signature.

As an alternative process of adding negative $\mu^{182} \mathrm{~W}$ core material to the lower mantle, Rizo et al. (2019) showed that Si-Mg-Fe oxides that exsolve from the outer core preferentially incorporate W over HSEs. These oxides are buoyant and would accumulate at the core-mantle boundary, potentially contributing to the selective transport of core-derived $\mathrm{W}$ to the lower mantle. It is conceivable that $\mathrm{S}$ with chondritic isotopic composition could be transported to the lower mantle through this or a similar process. However, an extension of either of the two models to account for a chondritic S isotopic composition of the high- 
$535 \quad{ }^{3} \mathrm{He} /{ }^{4} \mathrm{He}$ mantle remains highly hypothetical at present, as key parameters, such as

536 partitioning of $\mathrm{S}$ to $\mathrm{Si}-\mathrm{Mg}$-Fe oxides and the $\varepsilon^{34} \mathrm{~S}_{\text {metal-silicate }}$ fractionation factor at high $\mathrm{P}$ and

$537 \mathrm{~T}$, remain poorly constrained.

538 Although many open questions remain, the near-chondritic $\mathrm{S}$ isotopic composition of 539 the high- ${ }^{3} \mathrm{He} /{ }^{4} \mathrm{He}$ mantle provides a new important constraint for future models on the nature 540 and extent of chemical interactions between the core and the mantle during early planetary 541 differentiation, as well as in the present.

542

\section{CONCLUSIONS}

545 This study presents $\mathrm{S}$ concentration, speciation $\left(\mathrm{S}^{6+} / \Sigma \mathrm{S}\right)$ and isotope data acquired from 62

546 samples covering the main neovolcanic zones of Iceland. Focusing on undegassed, subglacial 547 basaltic glasses, the data provide a unique window to the sulfur isotopic evolution of OIB 548 magmas, constraining the $\delta^{34} \mathrm{~S}-\Delta^{33} \mathrm{~S}$ signatures of various Icelandic mantle components.

549 Undegassed Icelandic glasses contain between 300 and 1570 ppm sulfur and are mildly oxidized $\left(\mathrm{S}^{6+} / \Sigma \mathrm{S}=0.05-0.20\right)$. Melts reach sulfide saturation at $\mathrm{MgO} \approx 6 \mathrm{wt} . \%$, which leads to $\mathrm{S}$ and $\mathrm{Cu}$ depletions concurrent with increasing $\mathrm{S}^{6+} / \Sigma \mathrm{S}$ and $\delta^{34} \mathrm{~S}_{\mathrm{S}^{2-}}$ during subsequent melt evolution. The observed $\delta^{34} \mathrm{~S}_{\mathrm{S}^{2-}}(-2.5$ to $-0.1 \%)$ and $\Delta^{33} \mathrm{~S}(-0.035$ to $+0.011 \%)$ variability expressed by primitive Icelandic basalts exceeds that measured in MORBs. We infer an Icelandic mantle component with negative $\delta^{34} \mathrm{~S}_{\Sigma \mathrm{S}}=-2.5 \mathrm{wt} . \%$ and negative $\Delta^{33} \mathrm{~S}=-0.40 \%$ that is associated with MORB-like ${ }^{3} \mathrm{He} /{ }^{4} \mathrm{He}\left(8 \mathrm{R}_{\mathrm{A}}\right)$ and elevated $\mathrm{Ba} / \mathrm{La}(>12)$. We suggest that this mantle component (EMW) represents subduction fluid-enriched mantle wedge-type material present in the local upper mantle, that became entrained in the Iceland plume en route to the surface. High- ${ }^{3} \mathrm{He} /{ }^{4} \mathrm{He}$ and low- $\mu^{182} \mathrm{~W}$ samples from NRZ and ERZ converge toward $\Delta^{33} \mathrm{~S}$ and $\delta^{34} \mathrm{~S}_{\Sigma \mathrm{S}}$ values of $0 \%$. The near-chondritic $\delta^{34} \mathrm{~S}_{\Sigma \mathrm{S}}$ signature inferred for the primordial high- ${ }^{3} \mathrm{He} /{ }^{4} \mathrm{He}$ reservoir is difficult to reconcile with the sub-chondritic $\delta^{34} \mathrm{~S}_{\Sigma \mathrm{S}}$ signature of DMM, and may suggest that the two mantle domains experienced core extractions at different conditions during planetary differentiation, or alternatively, points toward a previously unidentified flux of S from the core to the high- ${ }^{3} \mathrm{He} /{ }^{4} \mathrm{He}$ reservoir.

\section{ACKNOWLEDGEMENTS}

566 This study has been supported by NordVulk fellowships awarded to ER and JGR, as well as a University of Iceland Research Fund Doctoral grant awarded to ER. SAH acknowledges 

at GTK was of great help during trace element analysis of the KVK samples. Simon Matthews and Maja Bar Rasmussen are thanked for commenting on early versions of the manuscript.

\section{REFERENCES}

Alt, J. C. (1995) Sulfur isotopic profile through the oceanic crust: sulfur mobility and seawater-crustal sulfur exchange during hydrothermal alteration. Geology, 23, 585-588.

Ariskin, A. A., Bychkov, K. A., Nikolaev, G. S., \& Barmina, G. S. (2018). The Comagmat-5: modeling the effect of Fe-Ni sulfide immiscibility in crystallizing magmas and cumulates. Journal of Petrology, 59(2), 283-298.

Beaudry, P., Longpré, M. A., Economos, R., Wing, B. A., Bui, T. H., \& Stix, J. (2018). Degassing-induced fractionation of multiple sulphur isotopes unveils post-Archaean recycled oceanic crust signal in hotspot lava. Nature communications, $9(1), 1-12$.

Bézos, A., Lorand, J. P., Humler, E., \& Gros, M. (2005). Platinum-group element systematics in Mid-Oceanic Ridge basaltic glasses from the Pacific, Atlantic, and Indian Oceans. Geochimica et Cosmochimica Acta, 69(10), 2613-2627.

Bottke, W. F., \& Norman, M. D. (2017). The late heavy bombardment. Annual Review of Earth and Planetary Sciences, 45.

Cabral, R. A., Jackson, M. G., Rose-Koga, E. F., Koga, K. T., Whitehouse, M. J., Antonelli, M. A., Farquhar, J., Day, J.M.D., \& Hauri, E. H. (2013). Anomalous sulphur isotopes in plume lavas reveal deep mantle storage of Archaean crust. Nature, 496(7446), 490-493.

Coplen, T. B., \& Krouse, H. R. (1998). Sulphur isotope data consistency improved. Nature, 392(6671), 32-32.

Delavault, H., Chauvel, C., Thomassot, E., Devey, C. W., \& Dazas, B. (2016). Sulfur and lead isotopic evidence of relic Archean sediments in the Pitcairn mantle plume. Proceedings of the National Academy of Sciences, 113(46), 12952-12956.

Ding, S., \& Dasgupta, R. (2018). Sulfur inventory of ocean island basalt source regions constrained by modeling the fate of sulfide during decompression melting of a heterogeneous mantle. Journal of Petrology, 59(7), 1281-1308.

Dixon, J. E., Bindeman, I. N., Kingsley, R. H., Simons, K. K., Le Roux, P. J., Hajewski, T. R., Swart, P., Langmuir, C.H., Ryan, J.G., Walowski, K.J., Wada, I., \& Wallace, P. J. (2017). Light stable isotopic compositions of enriched mantle sources: Resolving the dehydration paradox. Geochemistry, Geophysics, Geosystems, 18(11), 3801-3839.

Dottin III, J. W., Labidi, J., Lekic, V., Jackson, M. G., \& Farquhar, J. (2020a). Sulfur isotope characterization of primordial and recycled sources feeding the Samoan mantle plume. Earth and Planetary Science Letters, 534, 116073.

Dottin III, J. W., Labidi, J., Jackson, M. G., Woodhead, J., \& Farquhar, J. (2020b) Isotopic evidence for multiple recycled sulfur reservoirs in the Mangaia mantle plume. Geochemistry, Geophysics, Geosystems, e2020GC009081.

Gunnarsson-Robin, J., Stefánsson, A., Ono, S., \& Torssander, P. (2017). Sulfur isotopes in Icelandic thermal fluids. Journal of Volcanology and Geothermal Research, 346, 161-179.

Halldórsson, S. A., Barnes, J. D., Stefánsson, A., Hilton, D. R., Hauri, E. H., \& Marshall, E. W. (2016a). Subducted lithosphere controls halogen enrichments in the Iceland mantle plume source. Geology, 44(8), 679-682.

Halldórsson, S. A., Hilton, D. R., Barry, P. H., Füri, E., \& Grönvold, K. (2016b). Recycling of crustal material by the Iceland mantle plume: New evidence from nitrogen elemental and isotope systematics of subglacial basalts. Geochimica et Cosmochimica Acta, 176, 206-226.

Halldórsson, S. A., Bali, E., Hartley, M. E., Neave, D. A., Peate, D. W., Guðfinnsson, G. H., Bindeman, I., Whitehouse, M.J., Riishuus, M.S., Pedersen, G.B.M., Jakobsson, S., Askew, R., Gallagher, C.R., Guðmundsdóttir, E.R., Gudnason, J., Moreland, W.M., Óskarsson, B.V., Nikkola, P., Reynolds, H.I., 
Schmith, H., \& Thordarson, T. (2018). Petrology and geochemistry of the 2014-2015 Holuhraun eruption, central Iceland: compositional and mineralogical characteristics, temporal variability and magma storage. Contributions to Mineralogy and Petrology, 173(8), 64.

Hanan, B. B., Blichert-Toft, J., Kingsley, R., \& Schilling, J. G. (2000). Depleted Iceland mantle plume geochemical signature: Artifact of multicomponent mixing?. Geochemistry, Geophysics, Geosystems, 1(4).

Harðardóttir, S., Halldórsson, S. A., \& Hilton, D. R. (2018). Spatial distribution of helium isotopes in Icelandic geothermal fluids and volcanic materials with implications for location, upwelling and evolution of the Icelandic mantle plume. Chemical Geology, 480, 12-27.

Hauri, E. H., Maclennan, J., McKenzie, D., Gronvold, K., Oskarsson, N., \& Shimizu, N. (2018). CO2 content beneath northern Iceland and the variability of mantle carbon. Geology, 46(1), 55-58.

Jackson, M. G., Blichert-Toft, J., Halldórsson, S.A., Mundl-Petermeier, A., Bizimis, M., Kurz, M.D., Price, A.A., Harðardóttir, S. , Willhite, L.N.,. Breddam, K., Becker, T.W., Fischer, R.A. (2020) Ancient helium and tungsten isotopic signatures preserved in mantle domains least modified by crustal recycling. Proceedings of the National Academy of Sciences, 117(49), 30993-31001.

Jégo, S. \& Dasgupta, R (2013). Fluid-present melting of sulfide-bearing ocean-crust: experimental constraints on the transport of sulfur from subducting slab to mantle wedge. Geochimica et Cosmochimica Acta, 110, $106-134$.

Jenner, F. E., O'Neill, H. S. C., Arculus, R. J., \& Mavrogenes, J. A. (2010). The magnetite crisis in the evolution of arc-related magmas and the initial concentration of $\mathrm{Au}, \mathrm{Ag}$ and $\mathrm{Cu}$. Journal of Petrology, 51(12), 2445-2464.

Johnston, D. T. (2011). Multiple sulfur isotopes and the evolution of Earth's surface sulfur cycle. Earth-Science Reviews, 106(1-2), 161-183.

Jugo, P.J., Wilke, M., \& Botcharnikov, R.E. (2010). Sulfur K-edge XANES analysis of natu- ral and synthetic basaltic glasses: implications for $\mathrm{S}$ speciation and $\mathrm{S}$ content as function of oxygen fugacity. Geochimica et Cosmochimica Acta, 74(20), 5926-5938.

Labidi, J., Cartigny, P., Birck, J. L., Assayag, N., \& Bourrand, J. J. (2012). Determination of multiple sulfur isotopes in glasses: A reappraisal of the MORB 834 S. Chemical Geology, 334, 189-198.

Labidi, J., Cartigny, P., \& Moreira, M. (2013). Non-chondritic sulphur isotope composition of the terrestrial mantle. Nature, 501(7466), 208-211.

Labidi, J., Cartigny, P., Hamelin, C., Moreira, M., \& Dosso, L. (2014). Sulfur isotope budget (32S, 33S, 34S and 36S) in Pacific-Antarctic ridge basalts: A record of mantle source heterogeneity and hydrothermal sulfide assimilation. Geochimica et Cosmochimica Acta, 133, 47-67.

Labidi, J., Cartigny, P., \& Jackson, M. G. (2015). Multiple sulfur isotope composition of oxidized Samoan melts and the implications of a sulfur isotope 'mantle array' in chemical geodynamics. Earth and Planetary Science Letters, 417, 28-39.

Labidi, J., \& Cartigny, P. (2016). Negligible sulfur isotope fractionation during partial melting: Evidence from Garrett transform fault basalts, implications for the late-veneer and the hadean matte. Earth and Planetary Science Letters, 451, 196-207.

Labidi, J., Shahar, A., Le Losq, C., Hillgren, V. J., Mysen, B. O., \& Farquhar, J. (2016). Experimentally determined sulfur isotope fractionation between metal and silicate and implications for planetary differentiation. Geochimica et Cosmochimica Acta, 175, 181-194.

Lee, C. T. A., Luffi, P., Chin, E. J., Bouchet, R., Dasgupta, R., Morton, D. M., Le Roux, V., Yin, Q., \& Jin, D. (2012). Copper systematics in arc magmas and implications for crust-mantle differentiation. Science, 336(6077), 64-68

Leeman, W. P., Carr, M. J., \& Morris, J. D. (1994). Boron geochemistry of the Central American volcanic arc: constraints on the genesis of subduction-related magmas. Geochimica et Cosmochimica Acta, 58(1), 149168.

Li, J. L., Schwarzenbach, E. M., John, T., Ague, J. J., Huang, F., Gao, J., Klemd, R., Whitehouse, M., \& Wang, X. S. (2020). Uncovering and quantifying the subduction zone sulfur cycle from the slab perspective. Nature Communications, $11(1), 1-12$.

Macpherson, C. G., Hilton, D. R., Day, J. M., Lowry, D., \& Grönvold, K. (2005). High- ${ }^{3} \mathrm{He} /{ }^{4} \mathrm{He}$, depleted mantle and low- ${ }^{18} \mathrm{O}$, recycled oceanic lithosphere in the source of central Iceland magmatism. Earth and Planetary Science Letters, 233(3-4), 411-427.

Mukhopadhyay, S. (2012). Early differentiation and volatile accretion recorded in deep-mantle neon and xenon. Nature, 486(7401), 101-104.

Mundl, A., Touboul, M., Jackson, M. G., Day, J. M., Kurz, M. D., Lekic, V., Helz, R.T., \& Walker, R. J. (2017). Tungsten-182 heterogeneity in modern ocean island basalts. Science, 356(6333), 66-69.

Mundl-Petermeier, A., Walker, R. J., Jackson, M. G., Blichert-Toft, J., Kurz, M. D., \& Halldórsson, S. A. (2019). Temporal evolution of primordial tungsten- 182 and ${ }^{3} \mathrm{He} /{ }^{/ 4} \mathrm{He}$ signatures in the Iceland mantle plume. Chemical Geology, 525, 245-259. 

Anomalous $182 \mathrm{~W}$ in high $3 \mathrm{He} / 4 \mathrm{He}$ ocean island basalts: Fingerprints of Earth's core? Geochimica et Cosmochimica Acta, 271, 194-211.

Ono, S., Wing, B., Rumble, D., \& Farquhar, J. (2006). High precision analysis of all four stable isotopes of sulfur $\left({ }^{32} \mathrm{~S},{ }^{33} \mathrm{~S},{ }^{34} \mathrm{~S}\right.$ and $\left.{ }^{36} \mathrm{~S}\right)$ at nanomole levels using a laser fluorination isotope-ratio-monitoring gas chromatography-mass spectrometry. Chemical Geology, 225(1-2), 30-39.

Ono, S., Keller, N. S., Rouxel, O., \& Alt, J. C. (2012). Sulfur-33 constraints on the origin of secondary pyrite in altered oceanic basement. Geochimica et Cosmochimica Acta, 87, 323-340.

Ranta, E., Barnes, J.D., Halldórsson, S.A., Jónasson, K., Stefánsson A. (2021). Chlorine isotope ratios record magmatic brine assimilation during rhyolite genesis. Geochemical Perspectives Letters, 16, 35-39.

Rasmussen, M. B., Halldórsson, S. A., Gibson, S. A., \& Guðfinnsson, G. H. (2020). Olivine chemistry reveals compositional source heterogeneities within a tilted mantle plume beneath Iceland. Earth and Planetary Science Letters, 531, 116008.

Reekie, C. D. J., Jenner, F. E., Smythe, D. J., Hauri, E. H., Bullock, E. S., \& Williams, H. M. (2019). Sulfide resorption during crustal ascent and degassing of oceanic plateau basalts. Nature communications, 10(1), 111.

Richter, M., Nebel, O., Maas, R., Mather, B., Nebel-Jacobsen, Y., Capitanio, F. A., Dick, H.J.B., \& Cawood, P. A. (2020). An Early Cretaceous subduction-modified mantle underneath the ultraslow spreading Gakkel Ridge, Arctic Ocean. Science advances, 6(44), eabb4340.

Rizo, H., Andrault, D., Bennett, N. R., Humayun, M., Brandon, A., Vlastélic, I., Moine, B., Poirier, A., Bouhifd, M.A. \& Murphy, D. T. (2019). ${ }^{182} \mathrm{~W}$ evidence for core-mantle interaction in the source of mantle plumes. Geochem. Perspect. Lett., 11, 6-11.

Shorttle, O., \& Maclennan, J. (2011). Compositional trends of Icelandic basalts: Implications for short-length scale lithological heterogeneity in mantle plumes. Geochemistry, Geophysics, Geosystems, 12(11).

Torssander, P. (1989). Sulfur isotope ratios of Icelandic rocks. Contributions to Mineralogy and Petrology, 102(1), 18-23.

Wallace, P. J., \& Edmonds, M. (2011). The sulfur budget in magmas: evidence from melt inclusions, submarine glasses, and volcanic gas emissions. Reviews in Mineralogy and Geochemistry, 73(1), 215-246.

Wieser, P. E., Jenner, F., Edmonds, M., Maclennan, J., \& Kunz, B. E. (2020). Chalcophile elements track the fate of sulfur at Kīlauea Volcano, Hawai'i. Geochimica et Cosmochimica Acta, 282, 245-275.

Wilde, S. A., Valley, J. W., Peck, W. H., \& Graham, C. M. (2001). Evidence from detrital zircons for the existence of continental crust and oceans on the Earth 4.4 Gyr ago. Nature, 409(6817), 175-178.

Yuan K. \& Romanowicz B. (2017) Seismic evidence for partial melting at the root of major hot spot plumes. Science 357, 393. 


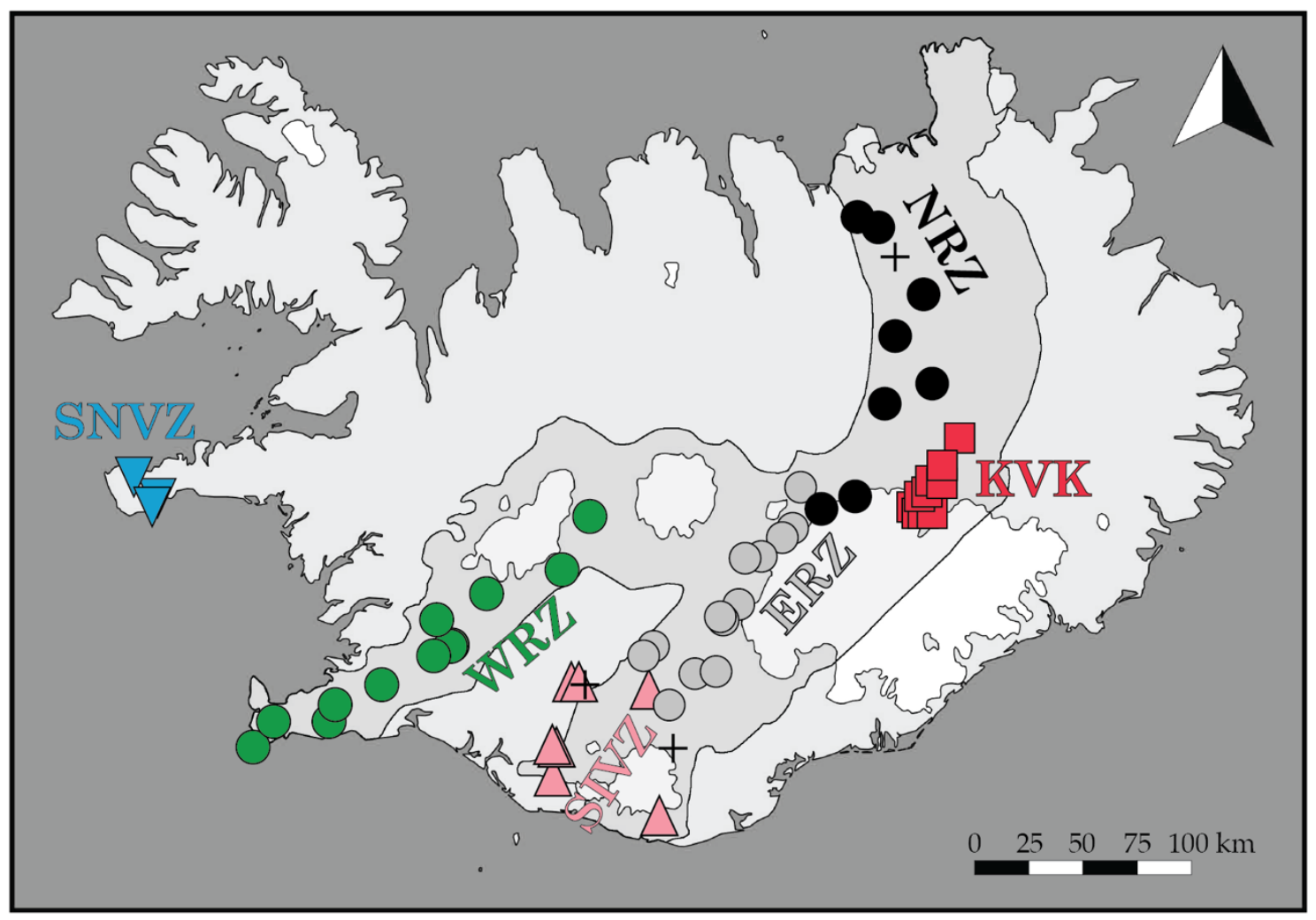

Figure 1 Map of Iceland showing sample locations of 59 subglacial pillow rim glass (circles, squares, triangles) and 3 subaerial lava samples (black crosses) analyzed in this study. The grey shaded area depicts presently active rift zones and the SIVZ propagating rift. Symbol types and colors used here to discriminate samples from different volcanic regions are maintained in all figures. Abbreviations: ERZ $=$ Eastern Rift Zone, $\mathrm{KVK}=$ Kverkfjöll volcanic system, NRZ = Northern Rift Zone, SIVZ = South Iceland Volcanic Zone, SNVZ = Snæfellsnes Volcanic Zone, WRZ = Western Rift Zone and Reykjanes Peninsula. 

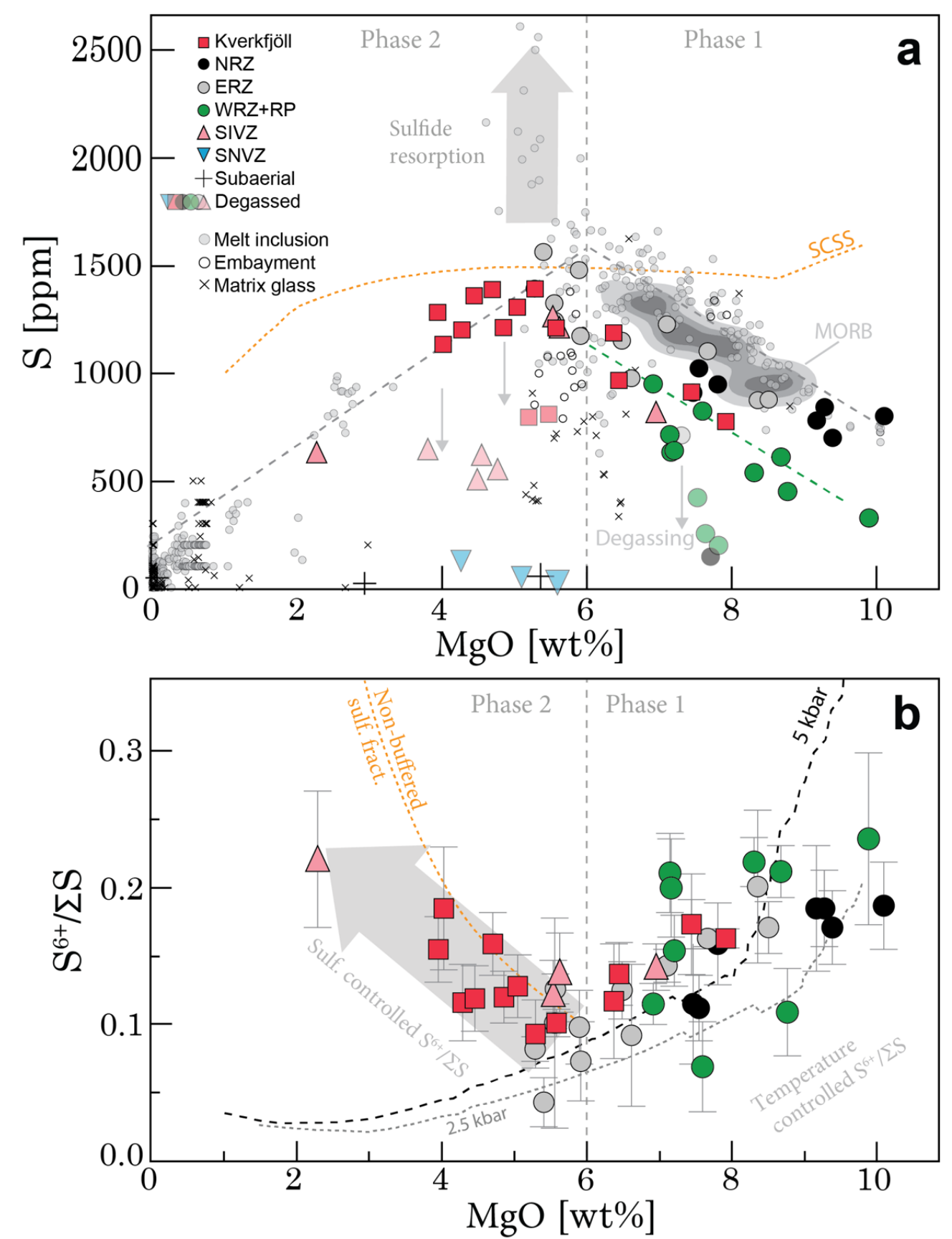

Figure 2 (a) Sulfur abundance versus $\mathrm{MgO}$. Data from this study are superimposed on published melt inclusion data from Iceland (compilation from Ranta et al. 2021). The melt inclusion data define an undegassed $\mathrm{S}$ evolution trend (dashed grey lines) with an inflection point at $\mathrm{MgO} \approx 6 \mathrm{wt} . \%$, separating two distinct phases of melt evolution. In Phase 1, the WRZ basalts define a parallel, lower$\mathrm{S}$ trend, indicated by the green dashed line. Samples deemed to have lost a significant amount of S by degassing are shown as transparent symbols (Supplementary Information). (b) Sulfur speciation versus MgO. Only undegassed samples are plotted (the full dataset is plotted in Fig. S3). Above MgO $>6 \mathrm{wt} . \%$, decreasing $\mathrm{S}^{6+} / \Sigma \mathrm{S}$ during fractional crystallization is controlled by temperature (Supplementary Information). Below $6 \mathrm{wt} . \% \mathrm{MgO}$, sulfide precipitation causes an increase in $\mathrm{S}^{6+} / \Sigma \mathrm{S}$. Non-buffered $\mathrm{S}^{6+} / \Sigma \mathrm{S}$ evolution trend (orange) was calculated based on measured/expected $\mathrm{S}$, estimated assuming loss of $\mathrm{S}^{2-}$ to a sulfide phase below $6 \mathrm{wt} . \% \mathrm{MgO}$. Two model trajectories are shown for $2.5 \mathrm{kbar}$ (grey dotted) and $5 \mathrm{kbar}$ (black dashed), calculated from Eq. 21, with $\mathrm{Fe}^{3+} / \Sigma \mathrm{Fe}$ and $\mathrm{T}$ vs. $\mathrm{MgO}$ for the model were derived by simulating isobaric fractional crystallization buffered at FMQ +0.2 in Comagmat 3.72 (Ariskin et al. 2018). The SCSS curve in (a) (orange) in was calculated for the $2.5 \mathrm{kbar}$ model after Fortin et al. (2015). 


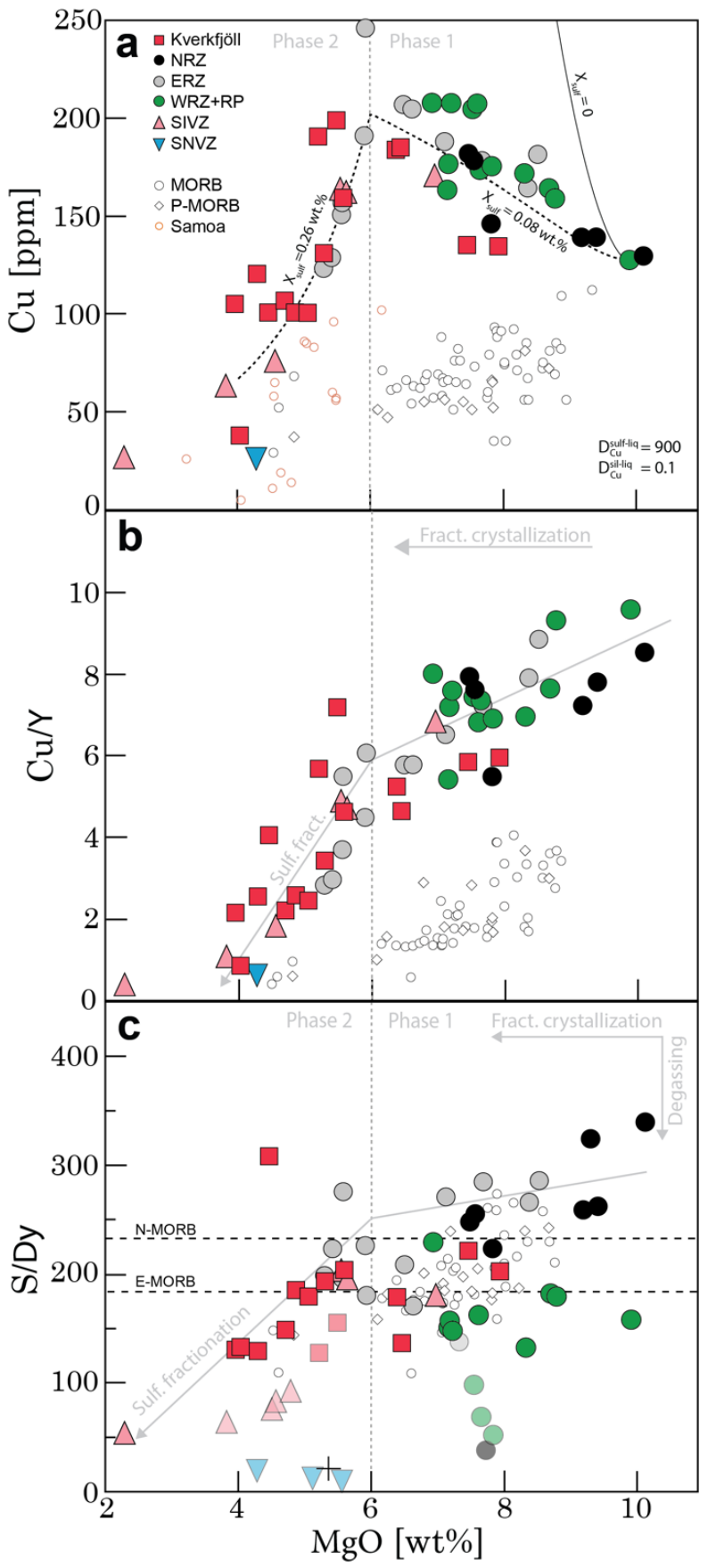

744 Figure 3 Effect of sulfide melt immiscibility. (a) $\mathrm{Cu}$ versus $\mathrm{MgO}$. A clear inflection point at $\mathrm{MgO} \approx 6$ wt.\% signals the onset, or acceleration, of sulfide fractionation. The observed trends indicate fractionation of about $0.08 \mathrm{wt} . \%$ sulfide melt between $\mathrm{MgO}=6-10 \mathrm{wt} . \%$ (Phase 1) and $0.26 \mathrm{wt} . \%$ between $\mathrm{MgO}=4-6 \mathrm{wt} . \%$ (Phase 2) (dashed grey line; see Supplementary material for model details). The modelled fractional crystallization trajectory for $\mathrm{X}_{\text {sulf }}=0$ (black line) greatly overestimates $\mathrm{Cu}$ concentrations. (b) $\mathrm{Cu} / \mathrm{Y}$ versus $\mathrm{MgO}$. Because $\mathrm{D}_{\mathrm{Cu}}^{\text {sil-liq }} \approx \mathrm{D}_{\mathrm{Y}}^{\text {sil-liq }}$, decreasing $\mathrm{Cu} / \mathrm{Y}$ may indicate slight fractionation of sulfide during Phase 1. (c) $\mathrm{S} / \mathrm{Dy}$ versus $\mathrm{MgO}$. The $\mathrm{S} / \mathrm{Dy}$ variability in undegassed, primitive ( $\mathrm{MgO}>6$ wt.\%) samples suggest either lower S/Dy in the WRZ and Kverkfjöll mantle compared to NRZ and ERZ, or, alternatively, buffering of primitive melt $\mathrm{S}$ concentrations during partial melting by mantle sulfides (Ding and Dasgupta 2018). MORB (white circles) data are sourced from Labidi et al. (2012, 2013, 2014) and Labidi and Cartigny (2016). Plume-influenced MORB data (P-MORB) covering the LOMU, Discovery and Shona anomalies in the South MidAtlantic Ridge are from Labidi et al. (2013). Samoan (orange circles) data are from Labidi et al. (2015). 

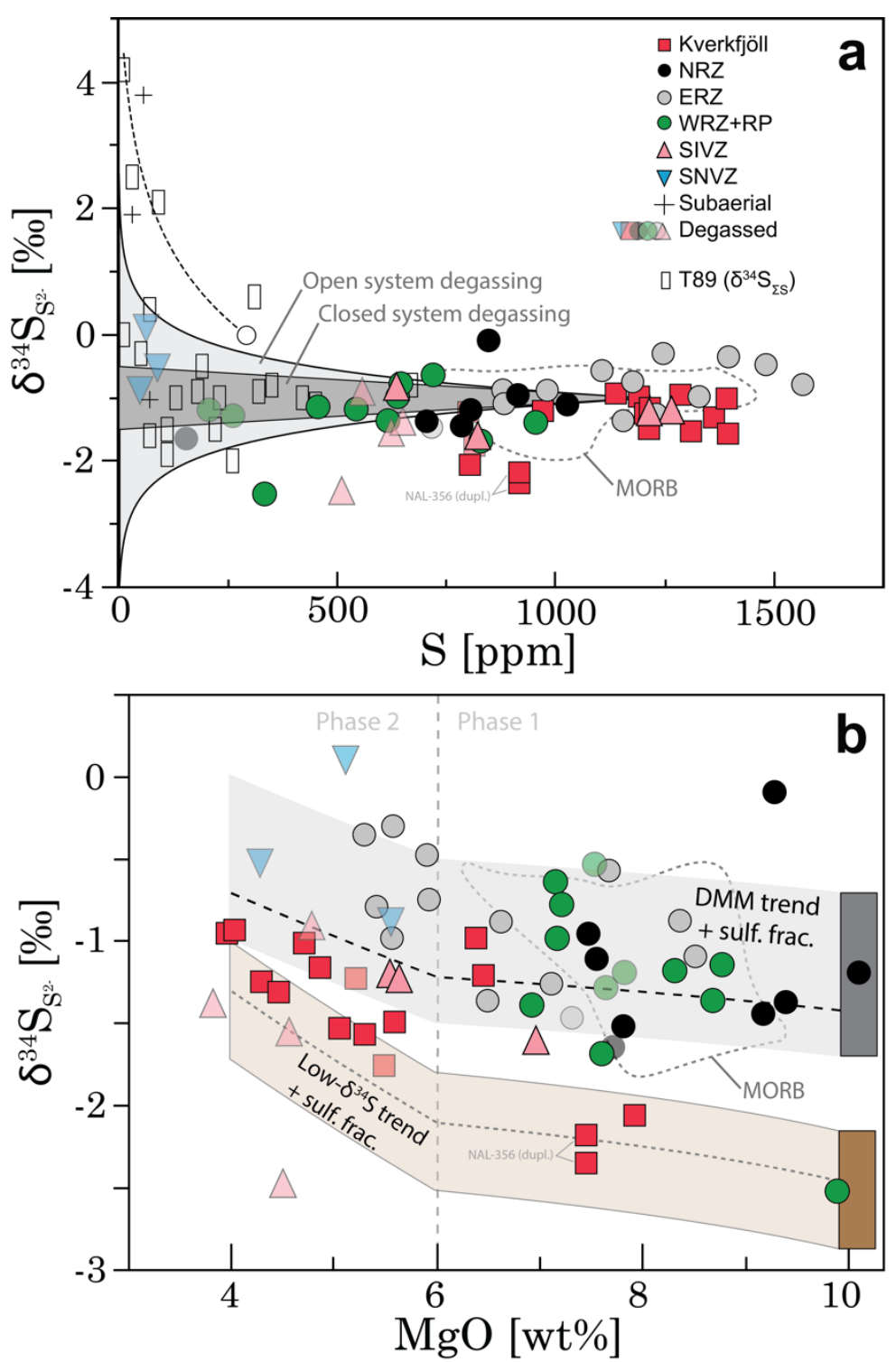

Figure 4 (a) $\delta^{34} \mathrm{~S}_{\mathrm{S}^{2-}}$ versus $\mathrm{S}$ concentrations. The effect of degassing on $\delta^{34} \mathrm{~S}$ in Icelandic samples is clearly illustrated by generally increasing $\delta^{34} \mathrm{~S}$ at low $\mathrm{S}$ concentrations. Large scatter in previously published data on Iceland (white rectangles; T89; Torssander 1989) demonstrates the advantage of using relatively undegassed subglacial glasses for studying pre-eruptive $\mathrm{S}$ isotope compositions. All undegassed Icelandic basalts have negative $\delta^{34} S_{S^{2-}}$ values. Shaded fields represent open (light grey) and closed system degassing (dark grey) of a basaltic melt with $\delta^{34} \mathrm{~S}_{\mathrm{S}^{2-}}=-1 \%$ and $\mathrm{S}=1200 \mathrm{ppm}$, assuming a fractionation factor of $\Delta^{34} S_{\text {gas-melt }}=0 \pm 0.5 \%$. Dashed black model line shows the effect open system degassing of a hypothetical undegassed rhyolitic melt with $\mathrm{S}=300 \mathrm{ppm}$ (white circle). Model details are explained in the Supplementary Information. (b) $\delta^{34} \mathrm{~S}_{\mathrm{S}^{2-}}$ versus MgO. Redox buffering of $\mathrm{S}$ following sulfide fractionation may lead to increasingly positive $\delta^{34} \mathrm{~S}_{\mathrm{S}^{2-}}$ values during melt evolution (shaded fields). However, a DMM-like mantle component cannot by itself explain the most negative $\delta^{34} \mathrm{~S}_{\mathrm{S}^{2-}}$ values in the primitive ( $\left.\mathrm{MgO}>6 \mathrm{wt} . \%\right)$ samples. Instead, an additional mantle component with more negative $\delta^{34} \mathrm{~S}$ signature is implicated. Modelled $\delta^{34} \mathrm{~S}_{\mathrm{S}^{2}}$ - trajectories for hypothetical DMM $\left(\mathrm{MgO}=10 \mathrm{wt} \%, \delta^{34} \mathrm{~S}_{\mathrm{S}^{2-}}=-1.44 \%, \mathrm{~S}=750 \mathrm{ppm}, \mathrm{S}^{6+} / \Sigma \mathrm{S}=0.185\right.$; similar to NAL-611) and "low- $\delta^{34} \mathrm{~S}$ component" $\left(\mathrm{MgO}=10 \mathrm{wt} \%, \delta^{34} \mathrm{~S}_{\mathrm{S}^{2-}}=-2.5 \%, \mathrm{~S}=400 \mathrm{ppm}, \mathrm{S}^{6+} / \Sigma \mathrm{S}=\right.$ 0.236 ; similar to MID-1) primary mantle melts are shown by dashed lines. The NRZ sample HS92-15 is an outlier with a clearly less negative $\delta^{34} \mathrm{~S}$ value of $-0.1 \%$ compared to other NRZ samples. Degassed samples are shown for reference (transparent symbols). MORB field drawn from the references given in Fig. 3. 

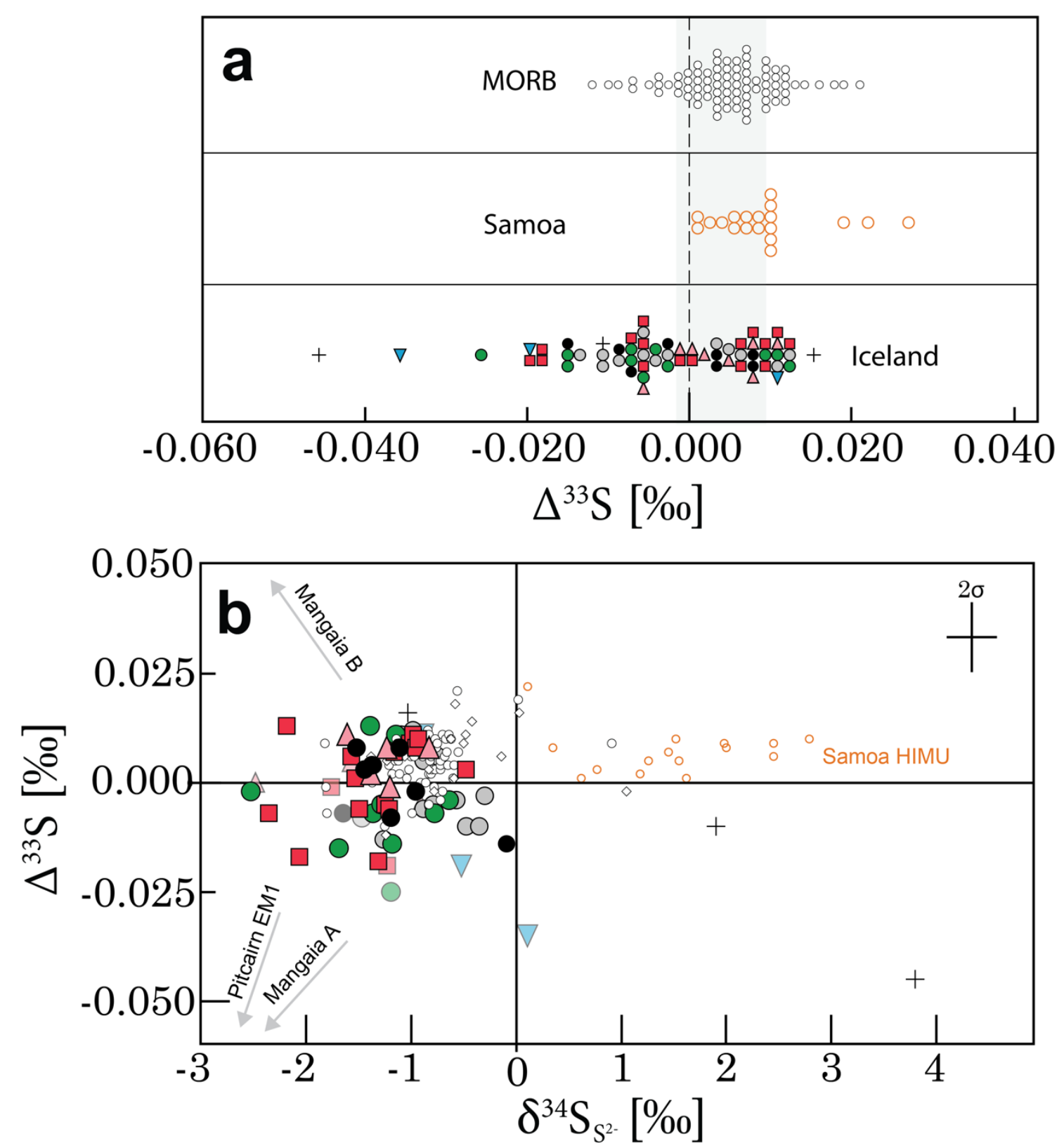

Figure 5 (a) A compilation of basaltic glass-derived $\Delta^{33} \mathrm{~S}$ data. Iceland samples overlap with MORBs and Samoan OIBs but are shifted toward more negative $\Delta^{33} \mathrm{~S}$. Negative $\Delta^{33} \mathrm{~S}$ values in MORBs are uncommon. Grey field shows the MORB average $(0.004 \pm 0.006,1 \sigma)$. (b) $\Delta^{33} \mathrm{~S}$ vs. $\delta^{34} \mathrm{~S}_{\mathrm{S}^{2-}}$ systematics. Available hotspot $\mathrm{S}$ isotope data from Iceland, Samoa (orange circles; Labidi et al. 2015; Dottin et al. 2020a), Mangaia and Pitcairn seem to describe a positive correlation between $\Delta^{33} \mathrm{~S}$ and $\delta^{34} \mathrm{~S}$ which is also present in the Archaean sediment record (Johnston et al. 2011). However, a break from this trend is represented by the Mangaian HIMU endmember $B\left(\delta^{34} \mathrm{~S}=-7.5 \%, \Delta^{33} \mathrm{~S}=+0.200\right.$ $\%$; Dottin et al. 2020b). Notably, very few data plot in the $2^{\text {nd }}$ quadrant. Grey arrows point toward the Mangaia HIMU endmember A $\left(\delta^{34} \mathrm{~S}=-22 \%, \Delta^{33} \mathrm{~S}=-0.600 \%\right.$; Cabral et al. 2014) and B and the Pitcairn EM1 component $\left(\delta^{34} \mathrm{~S}=-6 \%, \Delta^{33} \mathrm{~S}=-0.800 \%\right.$; Delavault et al. 2016). Degassed Samoan samples from Dottin et al. (2020), and MORBs that have assimilated seawater sulfate have been filtered out following Labidi et al. (2014). Symbols and MORB data as in Fig. 3. 


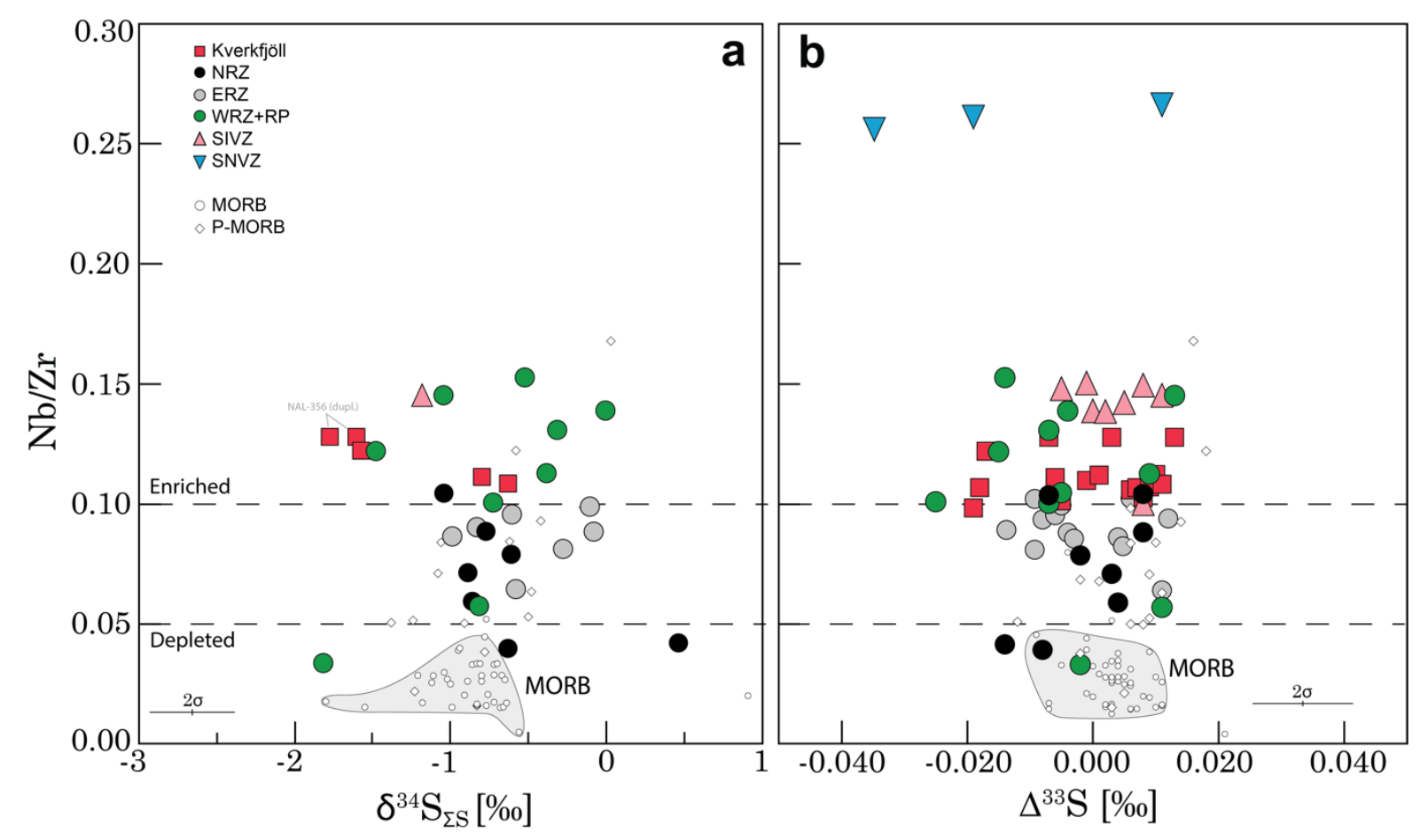

792 Figure 6 Trace element $(\mathrm{Nb} / \mathrm{Zr})$ enrichment vs. (a) $\delta^{34} \mathrm{~S}$ and (b) $\Delta^{33} \mathrm{~S}$. No clear correlation is seen 793 between trace element enrichment, as measured by $\mathrm{Nb} / \mathrm{Zr}$, and $\delta^{34} \mathrm{~S}$ or $\Delta^{33} \mathrm{~S}$. The greatest variation in $794 \delta^{34} \mathrm{~S}$ values is observed in both the depleted $(\mathrm{Nb} / \mathrm{Zr}<0.05)$ and the enriched glasses $(\mathrm{Nb} / \mathrm{Zr}>0.10)$, 795 while moderately enriched samples fall within the MORB field (light grey). Both depleted and enriched samples trend toward negative $\Delta^{33} S$ compared to MORBs. Samples that have experienced degassing or considerable sulfide fractionation $(\mathrm{MgO}<6 \mathrm{wt} . \%)$ may have altered $\delta^{34} \mathrm{~S}$ values and have been filtered out from (a) (see sections 4.1 and 4.2). MORB samples that have assimilated seawater sulfate have been filtered out from (a) following Labidi et al. (2014). The entire dataset is shown in (b), as $\Delta^{33} \mathrm{~S}$ is not affected by magmatic processes. MORB and P-MORB data as in Fig. 3. 
801

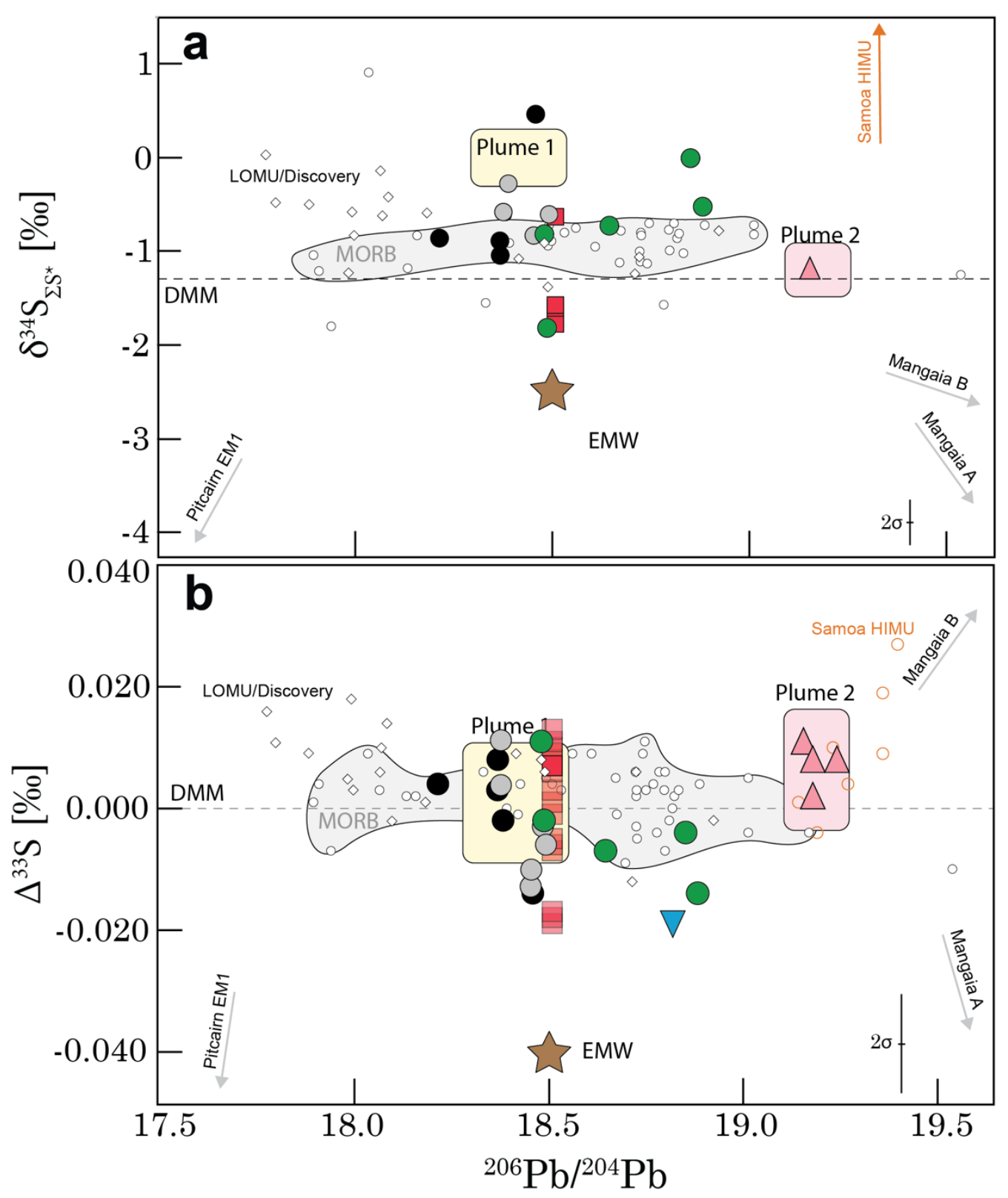

Figure 7 Lead and sulfur isotope relationships. (a) $\delta^{34} \mathrm{~S}_{\Sigma \mathrm{S}}$ versus ${ }^{206} \mathrm{~Pb} /{ }^{204} \mathrm{~Pb}$. The $\delta^{34} \mathrm{~S}_{\Sigma \mathrm{S}}$ values of Icelandic glasses partly overlap with those of MORBs (grey field). Notably, the anomalously negative $\delta^{34} \mathrm{~S}$ values at Kverkfjöll and the WRZ sample MID-1 are both associated with a ${ }^{206} \mathrm{~Pb} /{ }^{204} \mathrm{~Pb}$ value of 18.5. (b) Icelandic glasses show a greater variability in $\Delta^{33} S$ values compared to MORBs and have overall negative $\Delta^{33} \mathrm{~S}$ values that seem to converge at the EMW component. Notably, the SIVZ samples, that have the highest ${ }^{206} \mathrm{~Pb} /{ }^{204} \mathrm{~Pb}$ in Iceland $(>19.0)$ lack anomalous $\Delta^{33} \mathrm{~S}$ values. $\mathrm{Pb}$ isotope data for the Icelandic samples are sourced from Halldórsson et al. (2016a) and Jackson et al. (2020). The value ${ }^{206} \mathrm{~Pb} /{ }^{204} \mathrm{~Pb}=18.508$ reported for KVK-77 by Halldórsson et al. (2016a) is assumed for all KVK samples (transparent symbols). EMW = subduction fluid-enriched mantle wedge. Symbols and MORB data as in Fig. 3. 


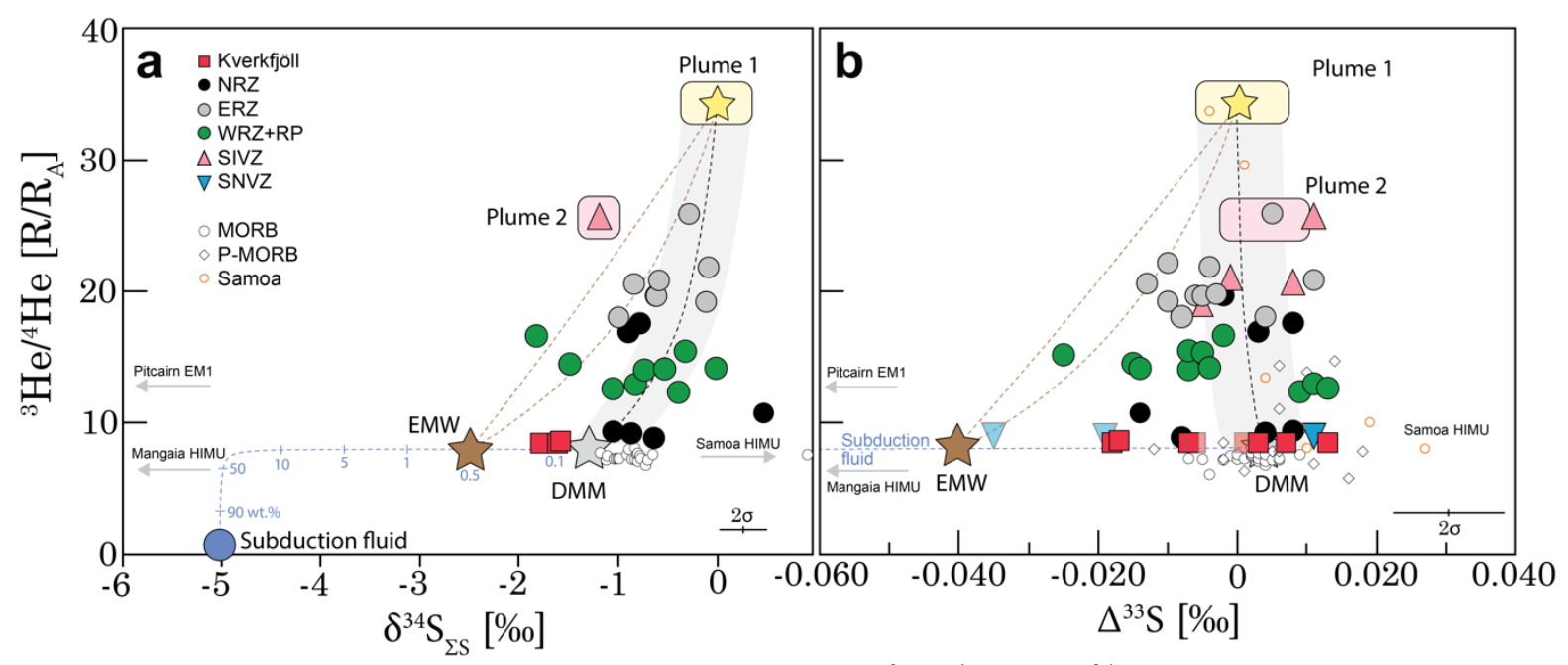

812

813

814

815

816

817

818

819

820

821

822

823

824

825

826

827

828

829

830

831

832

833

834

Figure 8 Sulfur and helium isotope relationships. (a) The ${ }^{3} \mathrm{He} /{ }^{4} \mathrm{He}$ vs. $\delta^{34} \mathrm{~S}_{\Sigma \mathrm{S}}$ systematics of Icelandic lavas can be explained by three-component mixing of DMM $\left({ }^{3} \mathrm{He} /{ }^{4} \mathrm{He}=8 \mathrm{R} / \mathrm{R}_{\mathrm{A}}, \delta^{34} \mathrm{~S}_{\Sigma \mathrm{S}}=-1.3 \%\right.$; grey star), Plume 1 mantle $\left({ }^{3} \mathrm{He} /{ }^{4} \mathrm{He}=33.6 \mathrm{R}_{\mathrm{A}}, \delta^{34} \mathrm{~S}_{\Sigma \mathrm{S}}=-0.3 \%\right.$; yellow star) and EMW (subduction fluid-enriched mantle wedge; ${ }^{3} \mathrm{He} /{ }^{4} \mathrm{He}=8 \mathrm{R}_{\mathrm{A}}, \delta^{34} \mathrm{~S}_{\Sigma \mathrm{S}}=-2.5 \%$; brown star). The radiogenic Plume 2 component (cf. Fig. 7) sampled by SIVZ lavas (pink field) has high ${ }^{3} \mathrm{He} /{ }^{4} \mathrm{He}\left(\sim 25 \mathrm{R}_{\mathrm{A}}\right)$ and $\Delta^{33} \mathrm{~S} \approx 0$ $\%$, but its $\delta^{34} \mathrm{~S}$ signature is only constrained by a single sample. The EMW component that gives rise to the low- $\delta^{34} \mathrm{~S}$ and low ${ }^{3} \mathrm{He} /{ }^{4} \mathrm{He}$ Kverkfjöll lavas is created by adding $\sim 0.5 \mathrm{wt} . \%$ subduction derived fluid (blue circle) with a composition of $\delta^{34} \mathrm{~S}_{\Sigma \mathrm{S}}=-5 \%, \mathrm{~S}=9620 \mathrm{ppm}$, similar to subduction fluids released from metasediments during devolatilization at $\sim 100 \mathrm{~km}$ depth (Li et al. 2020). (b) ${ }^{3} \mathrm{He} /{ }^{4} \mathrm{He}$ versus $\Delta^{33} \mathrm{~S}$. There is a clear tendency toward negative $\Delta^{33} \mathrm{~S}$ values in Icelandic lavas compared to DMM. This can be explained if the EMW component has a $\Delta^{33} \mathrm{~S}$ value of $-0.040 \%$, which requires a subduction fluid component with $\Delta^{33} \mathrm{~S}=-0.130 \%$. The $\Delta^{33} \mathrm{~S}$ variability decreases with increasing ${ }^{3} \mathrm{He} /{ }^{4} \mathrm{He}$ to values $\sim 0 \%$, which is taken as the $\Delta^{33} \mathrm{~S}$ signature of the Plume 1 component. Two SNVZ (BOTN-1 and OLAF-1) and Kverkfjöll samples (KVK-147 and KVK-168) with degassed ${ }^{3} \mathrm{He} /{ }^{4} \mathrm{He}$ are projected to the ${ }^{3} \mathrm{He} /{ }^{4} \mathrm{He}=9.0$ and $8.5 \mathrm{R}_{\mathrm{A}}$, which are representative of Snæfellsnes and Kverkfjöll lavas and geothermal fluids, respectively (Hardardóttir et al., 2018). Binary mixing curves are shown by dashed lines. Two binary mixing lines between EMW and Plume are shown scenario with $[\mathrm{He}]_{\mathrm{Plume}} /[\mathrm{He}]_{\mathrm{EMW}}$ of 1 (straight line) and 0.5 (curved line). End-member compositions are given in Table S6. Sample filtering, references and the Mangaia HIMU, Samoa and Pitcairn EM1 compositions as in Fig. 7. Helium isotope data for the Iceland samples from Macpherson et al. (2005), Füri et al. (2010) and Halldórsson et al. (2016b). MORB and P-MORB data as in Fig. 3. 


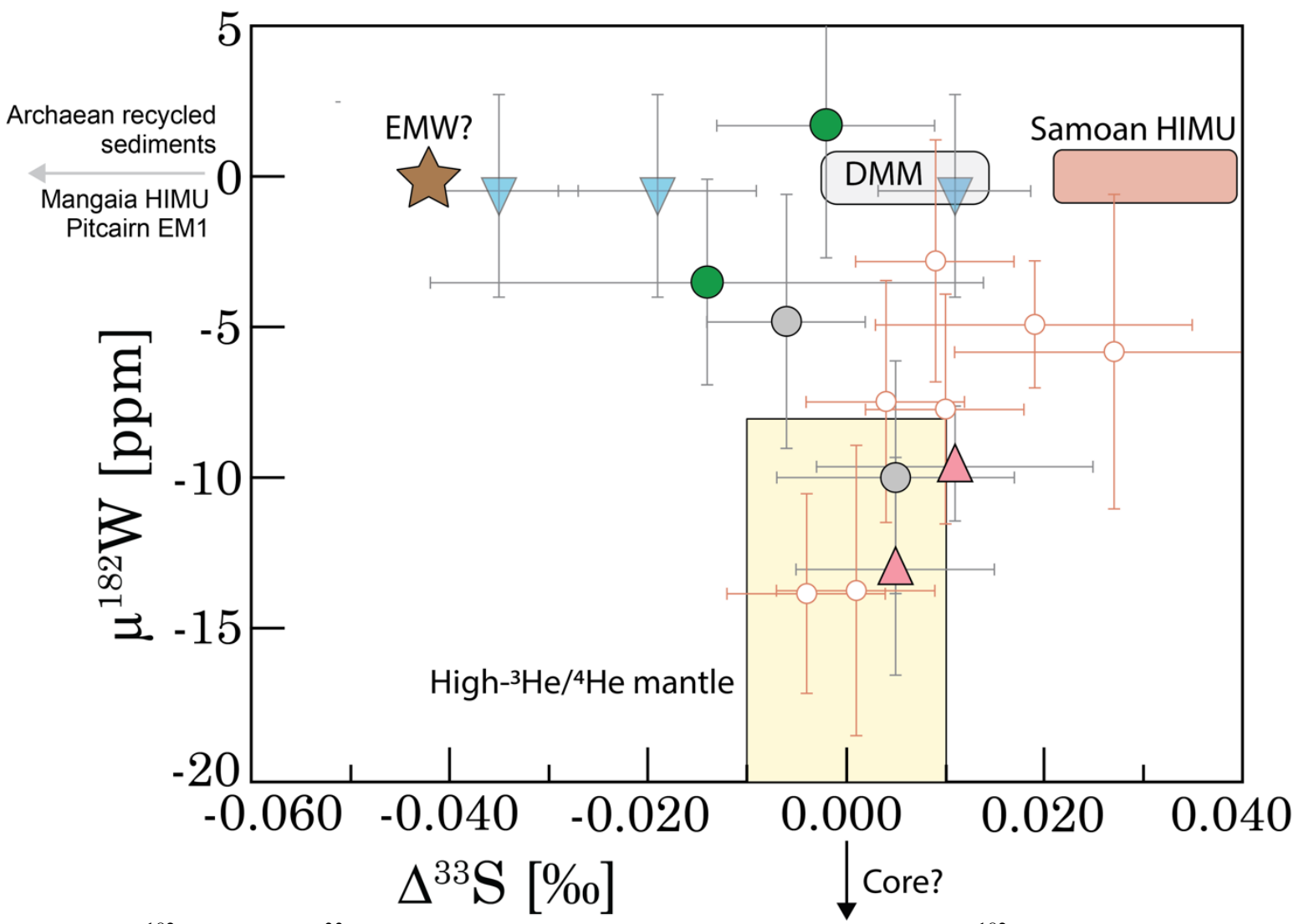

836 Figure $9 \mu^{182} \mathrm{~W}$ versus $\Delta^{33} \mathrm{~S}$. Icelandic and Samoan samples with negative $\mu^{182} \mathrm{~W}$ anomalies, that also 837 have high ${ }^{3} \mathrm{He} /{ }^{4} \mathrm{He}$, converge toward a chondritic $\Delta^{33} \mathrm{~S} \approx 0 \%$, which is taken as a signature of an 838 early-differentiated, primordial mantle reservoir. Samples with $\mu^{182} \mathrm{~W}$ approaching 0 exhibit larger variation in $\Delta^{33} \mathrm{~S}$, with Icelandic samples pulling toward negative and Samoan toward positive $\Delta^{33} \mathrm{~S}$ values. The $\mu^{182} \mathrm{~W}$ signature of the SNVZ samples is taken as the average of two other SNVZ samples SNS-206 (-0.6 ppm) and SNS-214 (-0.7 ppm) reported by Mundl-Petermeier et al. (2019). The $\mu^{182} \mathrm{~W}$ data for all Iceland samples are sourced from Mundl-Petermeier et al. (2019), except for sample A24 which is from Jackson et al. (2020). $\Delta^{33} \mathrm{~S}$ and $\mu^{182} \mathrm{~W}$ data for Samoa are sourced from Dottin et al. (2020a). Error bars represent $2 \mathrm{SE}$ for both $\mu^{182} \mathrm{~W}$ and $\Delta^{33} \mathrm{~S}$. Arrows point toward $\Delta^{33} \mathrm{~S}-\mu^{182} \mathrm{~W}$ compositions of Mangaia, Pitcairn and Earth's core based on Cabral et al. (2013), Labidi et al. (2013), Delavault et al. (2016) and Mundl et al. (2017). Symbols as in Fig. 3. 